\title{
Identifying Speculative Bubbles: A Two-Pillar Surveillance Framework
}




\title{
Identifying Speculative Bubbles: A Two-Pillar Surveillance Framework
}

\author{
Brad Jones
}




\title{
IMF Working Paper
}

Monetary and Capital Markets Department

Identifying Speculative Bubbles:

\section{A Two-Pillar Surveillance Framework ${ }^{1}$}

Prepared by Brad Jones

\section{Authorized for distribution by Luc Everaert}

\section{November 2014}

\section{This Working Paper should not be reported as representing the views of the IMF.} The views expressed in this Working Paper are those of the author(s) and do not necessarily represent those of the IMF or IMF policy. Working Papers describe research in progress by the author(s) and are published to elicit comments and to further debate.

\begin{abstract}
In the aftermath of the global financial crisis, the issue of how best to identify speculative asset bubbles (in real-time) remains in flux. This owes to the difficulty of disentangling irrational investor exuberance from the rational response to lower risk based on price behavior alone. In response, I introduce a two-pillar (price and quantity) approach for financial market surveillance. The intuition is straightforward: while asset pricing models comprise a valuable component of the surveillance toolkit, risk taking behavior, and financial vulnerabilities more generally, can also be reflected in subtler, non-price terms. The framework appears to capture stylized facts of asset booms and busts-some of the largest in history have been associated with below average risk premia (captured by the 'pricing pillar') and unusually elevated patterns of issuance, trading volumes, fund flows, and survey-based return projections (reflected in the 'quantities pillar'). Based on a comparison to past boom-bust episodes, the approach is signaling mounting vulnerabilities in risky U.S. credit markets. Policy makers and regulators should be attune to any further deterioration in issuance quality, and where possible, take steps to ensure the post-crisis financial infrastructure is braced to accommodate a re-pricing in credit risk.
\end{abstract}

JEL Classification Numbers: E44, F37, G12, G15, G18

Keywords: Asset bubbles, Market efficiency, Financial stability, Financial crises. Author's E-Mail Address: BJones@imf.org

\footnotetext{
${ }^{1}$ The author is grateful for comments from Tamim Bayoumi, Olivier Blanchard, Pete Dattels, Luc Everaert, Gaston Gelos, Shuntaro Hara, Matthew Jones, Tommaso Mancini-Griffoli, and Miguel Savastano.
} 
Abstract

I. Introduction .$\underline{5}$

II. A Review of Measurement and Inference Issues ..... .

III. Operationalizing Surveillance of Asset Bubbles: A Two-Pillar Framework

A. The Pricing Pillar.... $\frac{11}{13}$

B. The Quantities Pillar. .$\underline{22}$

IV. Concluding Remarks and Future Research. .$\underline{38}$

Annexes

Annex 1. Standard Testing Techniques for Speculative Bubbles.

Annex 2. Estimates of Required/Expected Returns

References

Boxes

Box 1. Problems in Formal Tests of Speculative Bubbles

Box 2. Problems in Formal Tests of Speculative Bubbles

Tables

Table 1. Two-Pillar Framework for Asset Bubble Surveillance. $\underline{13}$

Figures

Figure 1. Sensitivity to Discount Rates for the Fair Value of a Perpetuity ..... 11

Figure 2. The Rent/Price Ratio and Transaction Volumes: U.S. Housing Market ..................113

Figure 3. Empirical Determinants of Stock Returns ....................................................14

Figure 4. Valuation-based Asset Return Predictability.................................................16

Figure 5. Risk Premiums in the Years Before and After the Largest Busts ........................16

Figure 6. Risk Premia Preceding Large Busts, and Subsequent Asset Returns......................17

Figure 7. Lead Time between Start of Asset Bust and Onset of Recession............................17

Figure 8. Market-Implied Real Cost of Equity (Time Series) .........................................19

Figure 9. Market-Implied Real Cost of Equity across 25 Countries..................................19

Figure 10. Sovereign Bond Risk Premia (Time Series)..................................................20

Figure 11. Sovereign Bond Risk Premia (Cross Section) ................................................20

Figure 12. Yield-Based Expected Returns across Major U.S. Asset Classes ........................21

Figure 13. Average Expected Return across Major U.S. Asset Classes ...............................21

Figure 14. Current vs. Fair Value Spreads on U.S. High Yield Securities ............................22

Figure 15. Structured Credit and ABS Market Issuance....................................................24

Figure 16. High Yield Share of Credit Issuance Before/After Credit Blow-ups .....................25

Figure 17. U.S. Aggregate Net Equity Issuance vs. Equity Valuations.................................27

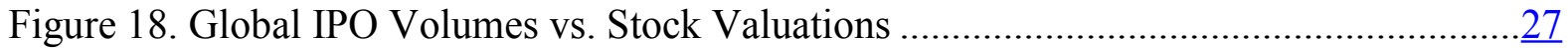


Figure 19. Issuance of Risky Credit Products .$\underline{29}$

Figure 20. Annual Sovereign Debt Issuance for First Time Issuers ................................. $\underline{30}$

Figure 21. U.S. Net Stock Issuance .........................................................................

Figure 22. Activity in Worldwide Equity Financing ................................................... $\frac{30}{32}$

Figure 23. Equity Trading Volumes During/After Stock Price Booms................................ 32

Figure 24. Trading Volumes in U.S. High Yield and Leveraged Loan Markets ..................... 33

Figure 25. Trading Volumes and Real Stock Prices ..................................................

Figure 26. Fund Flows in the Years Before a Bust........................................................

Figure 27. Correlation of Fund Flows and Asset Class Returns ....................................... $\frac{35}{36}$

Figure 28. Cumulative Investor Fund Flows: Past 5-Years ............................................ $\frac{36}{36}$

Figure 29. Size of Asset Class Funds vs. 5-Year Cumulative Fund Flows ............................. $\underline{36}$

Figure 30. Survey-based vs. Objective Measures of Future U.S. Stock Returns ................... 37 


\section{INTRODUCTION}

Financial history reads in many respects as a history of booms, bubbles and busts.

The infamous Dutch Tulip Mania (1634-1637), the French Mississippi Bubble (1719-20), the South Sea Bubble in the United Kingdom (1720), the first Latin American debt boom (1820s), and railway manias in the United Kingdom (1840s) and United States (1870s) are all notable early examples. ${ }^{2}$ In the past century, no busts have been more devastating than the Great Depression ushered in by the collapse of world stock markets in 1929. Over the past few decades, the Japanese Heisei bubble in the late 1980s, the various emerging market booms and busts in the 1980s and 1990s, and the equity mania in the late 1990s, offer examples of speculative frenzies gone awry. The threat to financial stability posed by large asset price movements has come into sharper focus over the past decade as the boom during the Great Moderation gave way to the collapse in global credit, real estate, and equity markets. Most recently, questions have been raised as to whether the prolonged use of unusually accommodative monetary policies may be fermenting another asset price bubble. ${ }^{3}$

Much of the debate over the existence and implications of speculative bubbles stems in the first instance from disagreement as to their measurable properties: the term "bubble" has been widely used to mean very different things. ${ }^{4}$ Bubble models typically emphasize the selffulfilling nature of expected future price changes based on the concept of 'resale optionality.' This enables asset prices to be decomposed into a rational intrinsic yield component (based on discounted future cash flows), and an irrational bubble component (based on expectations of future capital gains independent of fundamentals). On a different note, other researchers have focused upon the broader social dimensions of bubbles, with their tendency to engulf members of society who typically have little interest in financial matters (Mackay, 1841; Keynes, 1936; Kindleberger, 1978; Chancellor, 2000; Shiller, 2000a; Bonner and Rajiva, 2007; Reinhart and Rogoff, 2009; and Akerlof and Shiller, 2009). ${ }^{5}$ Yet definitional ambiguity

\footnotetext{
${ }^{2}$ As with many aspects of the speculative bubble literature, it should be noted that there remains considerable disagreement among scholars as to which of these episodes, among other widely cited manias, actually represent bona-fide bubbles.

${ }^{3}$ For instance, the Bank for International Settlements (2014) recently highlighted the dangers of "euphoria in financial markets ... it is hard to avoid the sense of a puzzling disconnect between the markets' buoyancy and underlying economic developments."

${ }^{4}$ References to "bubbles" throughout this paper are made in the general sense: (i) of an asset price so high that no reasonable (probability-weighted) future scenario for fundamentals could justify it, and (ii) where the expectation of future short-term price gains drives explosive self-fulfilling increases in prices (and possibly transaction volumes). Section II discusses measurement issues in more detail.

${ }^{5}$ It is not uncommon for authorities to monitor anecdotal information along these lines. For instance, to complement their formal quantitative analysis of home price dynamics, the Reserve Bank of Australia also closely monitor the number of property seminars held by finance companies targeting retail investors.
} 
and inference problems have long plagued formal studies of speculative bubbles.

Distinguishing irrational investor exuberance from the rational response to lower perceived risk is made difficult in real time by numerous issues, not least that it can only be known with absolute certainty ex-post whether the optimistic ex-ante projections embedded in asset prices were in fact justified.

Though much of the post-crisis literature has focused, understandably, on the role of credit growth in fermenting asset bubbles, the next major threat to financial stability may well take a different form. Moreover, as capital markets continue to expand in scale and scope, there are reasons to expect their dynamics to increasingly capture the attention of policy makers (Haldane, 2014; Stein, 2014; Feroli and others, 2014; Jones, 2014). In response, I introduce a simple two-pillar approach to bubble surveillance, based on both price and quantity data in the capital markets. ${ }^{6}$ Though by no means a conclusive solution to the age-old difficulties of crisis prediction, the framework appears to offer promise in capturing some of the stylized facts of asset booms and busts: some of the largest in history have been associated not just with below average risk premia (captured by the 'pricing pillar'), but also with unusually elevated patterns of issuance, trading volumes, fund flows, and survey-based return projections (i.e., the 'quantities pillar'). The ability to cross-reference signals from both pillars may give policy makers a richer understanding of the dynamics of asset price cycles and the threats they pose (if at all) to economic stability. Based on a comparison to historical boom-bust episodes, the framework currently points to mounting vulnerabilities in the riskier spectrum of credit markets.

The analysis proceeds as follows. A synthesis of measurement and inference issues that arise in the identification of speculative bubbles is presented in Section II. Section III outlines the contours of the two-pillar approach, drawing upon past asset boom and bust episodes to demonstrate the concept, and placing current developments in historical context. Concluding remarks and suggestions for future research are presented in Section IV.

\footnotetext{
${ }^{6}$ This two-pillar approach is motivated in part by the European Central Bank's (ECB) efforts to maintain price stability by cross-checking the complementary information stemming from 'real' developments with 'monetary' developments.
} 


\section{A REVIEW OF MEASUREMENT AND INFERENCE ISSUES}

Speculative bubbles are intuitively recognized to represent situations where market prices significantly exceed the level dictated by fundamentals. ${ }^{7}$ Yet broad agreement as to the properties of speculative bubbles has remained elusive virtually ever since the concept of speculation has been invoked (Box 1). These have not been debates over semantics, but rather quite fundamental issues with important policy implications. For instance how large must be the deviation of prices from those suggested by a fundamental-based model in order for it to be considered 'speculative' or 'irrational'? ${ }^{8}$ And for how long must the discrepancy between model-predicted and observed prices persist? Reflecting the so-called 'joint hypothesis problem,' how do we know a model of fair value, upon which the determination of a bubble is made, is in fact correctly specified in the first instance? Offering a related defense of his seminal efficient markets asset pricing paradigm, Eugene Fama asserted,

"I don't even know what a bubble means. These words have become popular. I don't think they have any meaning ... They have to be predictable phenomena ... It's easy to say prices went down, it must have been a bubble, after the fact. I think most bubbles are twenty-twenty hindsight. Now after the fact you always find people who said before the fact that prices are too high. People are always saying that prices are too high. When they turn out to be right, we anoint them. When they turn out to be wrong, we ignore them. They are typically right and wrong about half the time ... I didn't renew my subscription to the The Economist because they use the word bubble three times on every page. People have become entirely sloppy. "9

Theoretical studies have often focused upon the extrapolation of recent capital gains into the expectation of future capital gains, based on the concepts of 'resale optionality' and the self-fulfilling nature of expected future price changes. Analytically, this allows for a clean delineation between the rational and irrational component of asset prices. ${ }^{10}$ For instance, Hirshleifer (1977) suggests speculation refers to the purchase (sale) of a good for later re-sale (re-purchase), rather than for use, in the hope of profiting from an intervening

\footnotetext{
${ }^{7}$ Under this general concept, bubbles could include episodes where prices do not rise at all—for instance where (expectations of) fundamental values collapse but prices are unchanged or decline only modestly. Alternatively, a 'negative bubble' represents a situation where asset prices far undershoot the level implied by fundamentals. For the purposes of this paper and consistent with much of the related literature, our discussion of asset booms and bubbles refers to episodes where prices are rising rapidly (in absolute terms and relative to fundamentals).

${ }^{8}$ In his influential article entitled "Noise," Black (1986) argued that a market could still be considered efficient even if prices deviated in a range of plus 200 percent and minus 50 percent of fundamental value.

${ }^{9}$ Cassidy (2010).

${ }^{10}$ The fundamentally-derived cash flow yield is a stationary process, in contrast to the irrational bubble component which is non-stationary.
} 
price change. Harrison and Kreps (1978) suggest investors exhibit speculative behavior if the right to resell a stock makes them willing to pay more for it than they would pay if obliged to hold it forever. On this basis, an asset bubble exists where investors make a purchase only if they have the ability to subsequently sell the asset at some future date. ${ }^{11}$ Kindleberger (1987) defines a speculative bubble as a sharp rise in price of an asset or a range of assets in a continuous process, with the initial rise generating expectations of further rises and attracting new buyers-generally speculators, interested in profits from trading in the asset rather than its use or earning capacity. Stiglitz (1990) defines a bubble where the reason that the price is high today is only because investors believe that the selling price will be high tomorrowwhen 'fundamental' factors do not seem to justify such a price. Flood and Garber (1994) categorize a bubble where the positive relationship between price and its expected rate of change implies a similar relationship between price and its actual rate of change. In such conditions, the arbitrary, self-fulfilling expectation of price changes may drive actual price changes independently of market fundamentals. Shiller (2003, pp. 35, 38) describes a bubble in behavioral terms where irrational investors are attracted to an investment because "rising prices encourage them to expect, at some level of consciousness, more price increases. A feedback develops-as people become more and more attracted, there are more and more price increases ... the amplification mechanisms that make a bubble grow strong are just that price increases beget more price increases, through human psychology."

From a different perspective, Siegel (2003) states formulaically that "a period of rising (or falling) prices in an asset market can be described as a bubble (or negative bubble) at time $t$ if it can be shown that the realized return of the asset over a given future time period, that time period defined by the duration of the asset, can be shown to be inconsistent, i.e. more than two standard deviations from the expected return, given the historical risk and return characteristics of that asset at time $t$." This is an ex-post measure where the real time identification of irrational optimism (or pessimism) is impossible-the presence of a bubble can only be established once fundamental data have been realized over the maturity of the asset. In acknowledging there will almost always be ex-ante and ex-post disagreement about the objective measurement of bubbles, Asness (2014, p. 2) concludes somewhat more generally that to have content, the term bubble should indicate a price that no reasonable future outcome can justify.

\footnotetext{
${ }^{11}$ This definition ignores the fact that some investors will have a stronger preference for liquidity than others.
} 


\section{Box 1. Problems in Formal Tests of Speculative Bubbles}

Speculation has a long and colorful history. In Latin, the word 'speculator' describes a sentry whose job it was to 'look out' (speculare) for trouble, with arguably the earliest known historical cases of speculation taking place in ancient Rome during the Republic of the second century B.C. (Chancellor, 2000). Scottish journalist Charles Mackay (1841) was among the first to chronicle the history of popular and financial folly in his classic tome Extraordinary Popular Delusions and the Madness of Crowds: "Men, it has been well said, think in herds; it will be seen that they go mad in herds, while they only recover their senses slowly, and one by one" (Volume 1, p. 3). The tendency toward seemingly irrational behavior has featured prominently in the speculative bubble literature ever since Mackay's lucid description. Keynes (1936, p. 158) also offered an early attempt to descriptively delineate speculation "under the influence of mass psychology" from the (more legitimate) undertaking of 'enterprising investment': "the term speculation (refers to) the activity of forecasting the psychology of the market; the term enterprise to forecasting the prospective yield of assets over their whole life." These insights laid the groundwork for subsequent efforts by researchers to apportion asset prices into two components - an unbiased (rational) estimate of intrinsic yield, and a biased (irrational) estimate of expected capital gains.

The academic literature prior to the 1970s broadly defined 'speculation' along two lines. The first viewed speculation as a process for risk-transference, from risk averse 'hedgers' (for instance, physical commodity producers) to more risk tolerant commodity price 'speculators;' or from traders with already large risky positions to those with a greater ability to assume new risk. Thus in the tradition of Keynes (1930) and Hicks (1946), speculation could be considered a substitute for insurance markets. An alternative explanation, the 'knowledgeable-forecasting hypothesis,' proposed that differences in conviction in beliefs about the future (rather than the ability to take risks) better explained speculative behavior: an individual with the firm belief that prices will rise (fall) in the future will make speculative purchases (sales) today, with markets simply reflecting the consensus of beliefs about future supply-demand conditions rather than serving as an insurance function (Working, 1953, 1962; Rockwell, 1967). By the 1970s, academic interest in deriving theories of speculation quickly evolved into developing theories of speculative bubbles and the efficiency of markets more broadly.

Other sweeping (albeit less quantitative) historical analyses have emphasized the predominant feature of speculative asset bubbles as their tendency to draw in members of the general public who are typically aloof in monetary matters. In other words, bubbles can be distinguished from other episodes through their broader impact on society. ${ }^{12}$ Yet as

\footnotetext{
${ }^{12}$ In an early example, Mackay (1841) states of the seventeenth century Dutch Tulip Mania, "Nobles, citizens, farmers, mechanics, seamen, footmen, maid-servants, and even chimney-sweeps and old clotheswomen dabbled in tulips." The editorial of the New York Herald wrote in June 1857 that the U.S. railway boom appeared to "infect all classes of society - the country merchant is becoming a city stockjobber, and the honest country farmer has gone off among the gamblers in western land" (Sobel, 1968). As Kindleberger (1978) points out in his classic study of speculative manias: "There is nothing so disturbing to one's well being and judgment as to see a friend get rich. When the number of firms and households indulging in these practices grows large, bringing in segments of the population that are normally aloof from such ventures, speculation for profit leads
}

(continued...) 
colorful as these socio-behavioral descriptions might seem, an obvious limitation is they are not particularly amenable to formal testing.

Empirical tests of speculative bubbles, including those assessing early warning indicators in the context of financial crises, are forced to contend with other difficult measurement and inference issues. In setting threshold levels for asset price misalignments, policy makers have to balance the tradeoff between false negatives and false positives (see for example, Kaminsky and others, 1998; Alessi and Detken, 2009; and Gerdesmeier and others, 2009). If thresholds are set too high, this will increase the likelihood of failing to predict subsequent busts (Type 1 errors), while setting them too low can come at the cost of incurring frequent warnings of impending busts that do not materialize (Type 2 errors). Other complications arising from speculative bubble testing include the problems of small sample sizes (dealing with relatively rare events), the stability of estimated coefficients (in vs. out of sample), and quantitatively accounting for the pervasive irrational behavioral/social phenomema that are emphasized in descriptive accounts of speculative manias. ${ }^{13}$

Broadly speaking, formal tests of speculative asset price bubbles could be plagued by estimation and measurement limitations to such a degree that they may achieve little of substance in advancing the policy debate over the existence of bubbles, especially in real time - the domain in which policy makers operate (Box 2). As Gurkaynak, (2005, p. 27) concludes, "Bubble tests do not do a good job of differentiating between misspecified fundamentals and bubbles. This is not only a theoretical concern: For every test that 'finds' a bubble, there is another paper that disputes it ... The bubble tests teach us little about whether bubbles really exist or not."

\section{Box 2. Problems in Formal Tests of Speculative Bubbles}

In formal hypothesis testing, the acceptance or rejection of the existence of a speculative bubble is contingent on the model of proposed fundamentals and its embedded assumptions. As the prices of long duration assets are determined by expectations of future outcomes, fundamental-based models have to rely on unobservable estimates and are thus prone to misspecification (IMF, 2003). A misspecified model (especially those with omitted variables) may lead to the mistaken conclusion that a bubble exists; in this sense, the finding of a bubble is a catch-all for asset price movements not

away from normal, rational behavior to what has been described as a mania." Shiller (2000a, p.2) depicts a society-wide mania as the spread of "psychological contagion from person to person, in the process amplifying stories that might justify the price increase and bringing in a larger and larger class of investors, who, despite doubts about the real value of the investment, are drawn to it partly through envy of others' successes and partly through a gambler's excitement."

${ }^{13}$ A helpful summary of the various issues encountered in econometric tests of market efficiency and speculative bubbles are presented in Campbell and others (1997) and Gurkaynak (2005). 
captured by the fundamental model (Hamilton and Whiteman, 1985; West, 1987). This is related to the joint hypothesis problem: any test for speculative bubbles must first assume a baseline reference model for equilibrium prices in an efficient market - what appears to be a speculative bubble might be no such thing if the baseline equilibrium pricing model is itself incorrect (Fama, 1991; Campbell and others, 1997). For this reason, the burden of proof may well reside with proponents of the speculative bubble thesis to demonstrate in the first instance that their model of fundamentals is valid (Flood and Garber, 1994). Rosser (2000, p. 107) neatly summarizes the inference problem: "the most fundamental (problem) is determining what is fundamental." A summary of the intuition behind the range of formal testing techniques typically employed in studies attempting to prove/disprove the existence of speculative bubbles is presented in Annex 1.

A simple example illustrates how a small change in fundamental assumptions can dramatically impact the assessment of asset 'fair value.' Figure 1 shows how the present value of an infinitive-lived asset (such as a stock) paying a cash flow of 100 changes as the discount rate increases in increments of 50 basis points (along the horizontal axis). For instance, if the discount rate were to increase just 50 basis points, from 1 to 1.5 percent, the asset fair value collapses 33 percent (from 10,000 to 6,667). Expressed another way, it requires only minor decreases in long-run discount rate assumptions to justify elevated asset prices, and thus reject the hypothesis that a speculative bubble exists.

\section{Figure 1. Sensitivity to Discount Rates for Fair Value Perpetuity Estimates} (Paying \$100)

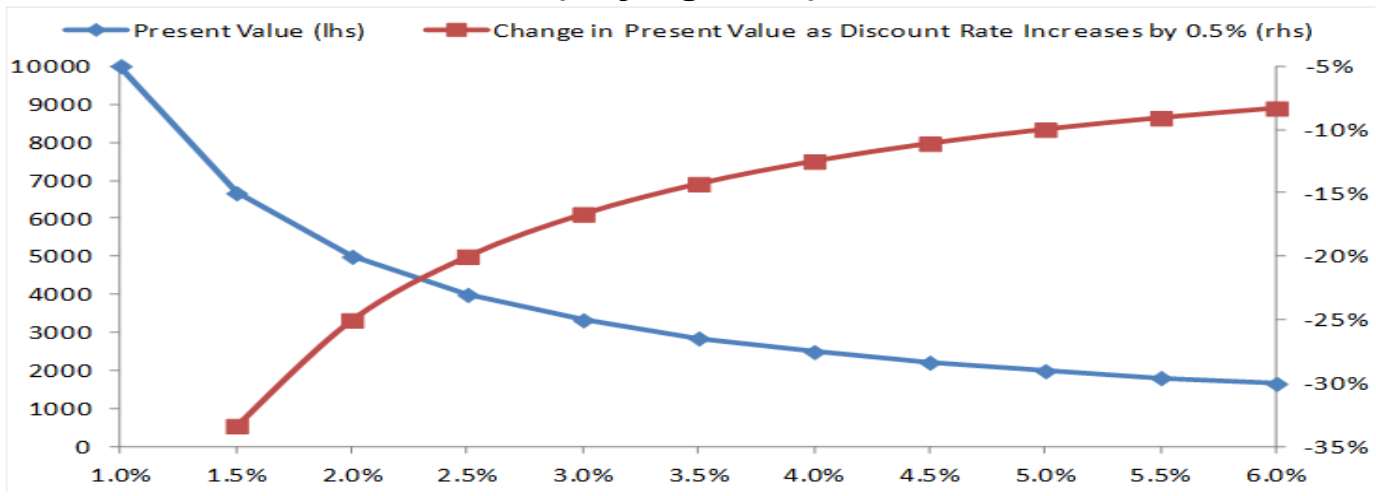

Source: Author's estimates

Notes: This example is based on the version of the Gordon Growth Model used to value perpetuities, where the present value $=$ next year's cash flow / (risk free rate + risk premium - expected growth rate).

\section{Operationalizing Surveillance OF ASSet bubbles: A Two-Pillar FRAMEWORK}

The difficulties associated with identifying asset bubbles in real time suggests a need for policy makers to survey and cross-validate information from a variety of approaches and metrics. Unusually stretched asset prices might reflect rationally lower compensation for risk, the limits to arbitrage, or irrational behavioral errors. It is unlikely any single variable or model specification will ever be able to offer irrefutable evidence, in real time, that an irrational bubble is in progress - by definition, bubbles can only be identified with complete certainty ex-post. Without the benefit of hindsight to inform their real time assessments, 
policy makers need to rely on a diverse and timely suite of measures to highlight the accumulation of financial vulnerabilities and concomitant threats to financial stability. It is in this context that supplemental non-price data might help provide authorities with a richer, more nuanced understanding of risk taking behavior-potentially enhancing the quality of decision making under uncertainty - even if (as is almost certainly the case) this approach falls short of the proverbial magic bullet solution to the difficulties of crisis prediction. In a pragmatic sense, 'perfect should not be the enemy of good.'

In recognition of these issues, this paper proposes a conceptually straightforward surveillance approach based on two distinct though complementary pillars: one that is price-based (capturing swings in risk premia or required returns), and another that is quantity-based (tracking issuance, transaction volumes, investor fund flows, and investor surveys; see Table 1). Periods where (i) risk premiums have been compressed to abnormally low levels, and (ii) issuance, trading activity, fund flow data, and survey-based return expectations are unusually elevated, are likely to warrant particular attention from policy makers. ${ }^{14}$ Though most of the following analysis is focused on capital markets, this framework can be equally applied to real estate markets. To briefly illustrate, Figure 2 depicts the relationship between the rent/price ratio (i.e., the rental yield, a conventional valuation metric) and transaction volumes in the U.S. housing market over the 1969-2014 period. The U.S. housing bubble of the mid 2000s was notable in that it constituted a three standard deviation event not just in valuation terms, but also in (non-price) quantity terms. As outlined below, asset booms characterized by extremely unusual valuations and turnover present a significant challenge to benign rational-based explanations. More forcefully, one of the paper's main contentions is that they should put policy makers on high alert.

\footnotetext{
${ }^{14}$ This framework is designed to address the 'identification problem.' As to the 'implication problem,' policy makers will need to be guided by other metrics, including but not limited to those assessing the degree of interconnectedness across institutions, credit growth dynamics, potential wealth effects, etc..
} 


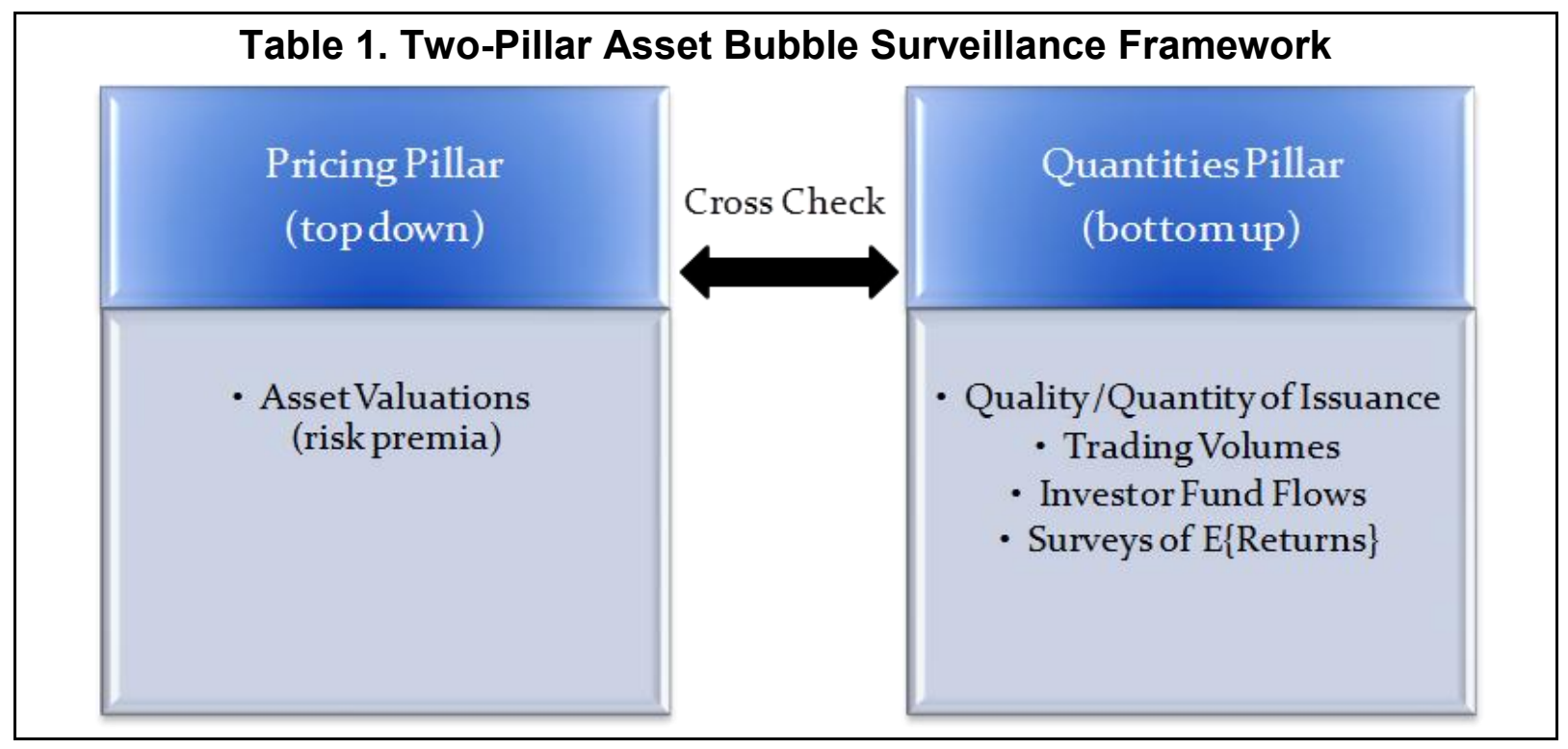

Figure 2. The Rent/Price Ratio and Transaction Volumes: U.S. Housing Market

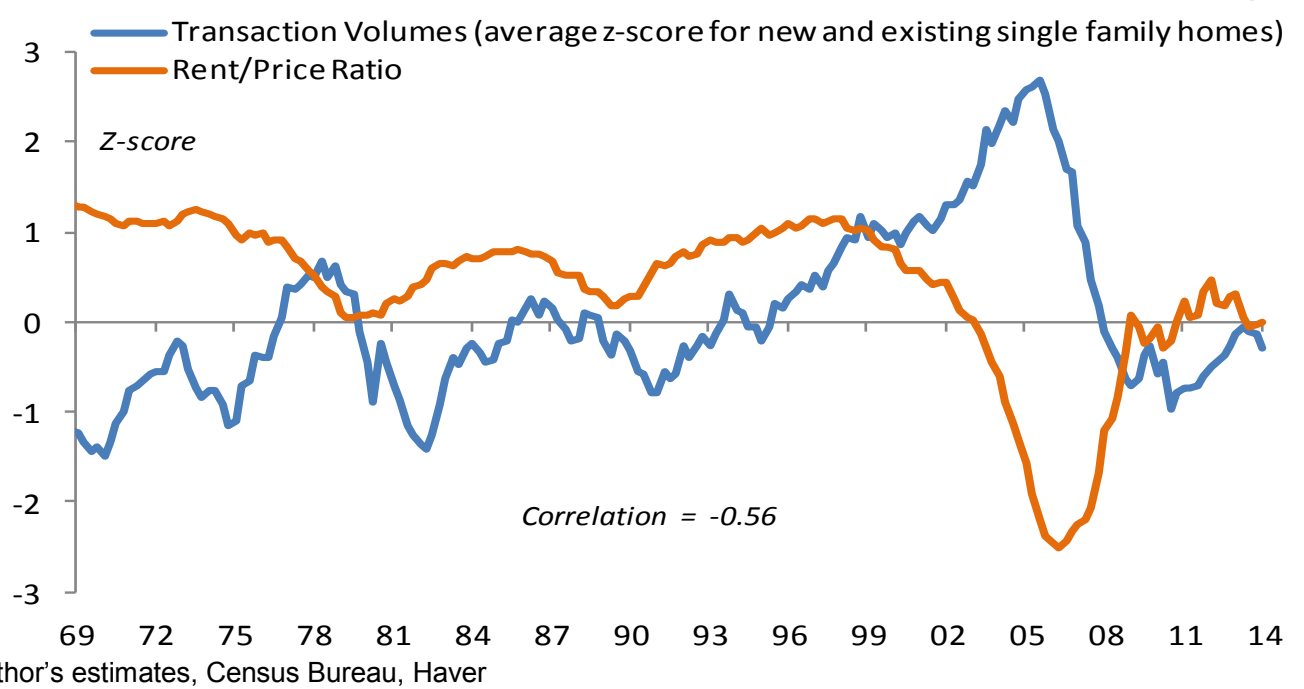

Source: Author's estimates, Census Bureau, Haver

\section{A. The Pricing Pillar}

Over time, the search for explanations of asset price movements has shifted in focus. Early asset pricing theories emphasized the role of changes in expected cash flows as the key driver of variability in asset prices, with discount rates (comprising risk free rates and a risk premium) assumed constant (Fama, 1970). What appeared to be unusually high valuation ratios could be justified only by expectations of unusually strong cash flow (dividend or rental) growth in the future. However, a large body of work subsequently showed large asset price increases to have been poor predictors of future cash flow growth (see most recently, Cochrane, 2011; and Williams, 2013), with time variation in discount rates established as the 
dominant source of variation in asset prices. ${ }^{15}$ As Figure 3 demonstrates, while U.S. stock market returns appear to be strongly negatively correlated with contemporaneous changes in risk premia, the relationship between stock returns and changes in either long-term risk-free interest rates or long-term growth expectations is considerably more muted. ${ }^{16}$

\section{Figure 3. Empirical Determinants of Stock Returns (correlation of excess and real S\&P 500 returns to contemporaneous changes in growth expectations, risk-free rates, and the equity risk premium)}

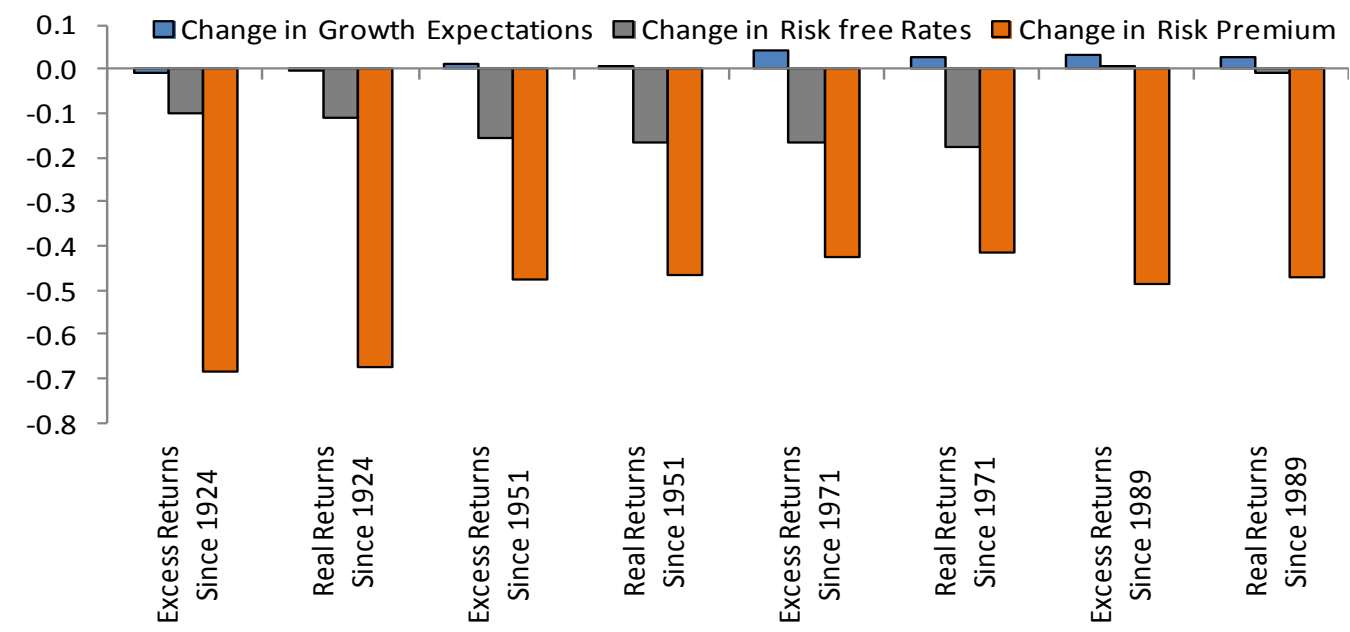

Source: Author's estimates, Consensus Economics, Bloomberg

Notes: All data expressed in monthly terms. Sample periods reflect the beginning of the data set (1924), the Treasury-Fed Accord (1951), the end of the Bretton Woods system of fixed exchange rates (1971), and the beginning of the dataset on survey-based expectations of real growth and inflation compiled by Consensus Economics (1989). Prior to 1989, long-term nominal growth expectations are proxied by a ten year moving average of nominal GDP growth. The risk free rate is the 10 year Treasury yield. The equity risk premium is an average of three separate measures (see Annex 2 for details).

For surveillance purposes, asset valuation measures (ideally using real-time information) should demonstrate at least some degree of predictive power over subsequent returns, and perhaps more importantly, display unusual behavior preceding large asset busts. Based on six decades of annual data (1953-2013), Figure 4 plots the explanatory power of valuation measures over subsequent returns for each of the major U.S. asset classes (represented by the $\mathrm{R}^{2}$ from regressions of asset returns over different holding periods on initial levels of

\footnotetext{
${ }^{15}$ At the most fundamental level, asset prices can be expressed as function of expected future cash flows, discounted by (a series of) risk free rates and a risk premium. As market prices and risk-free interest rates can be directly observed, and expected cash flows reasonably proxied, market-implied risk premiums can be backed out as a residual term. To paraphrase Abramovitz (1956), risk premiums can also be interpreted as "a measure of our ignorance." A more complete theoretical model incorporates a fourth term, the expected asset re-sale value, which enables the intrinsic earnings capacity (or cash flow yield) of the asset to be isolated from the speculative bubble component based on the expectation of capital gains (unrelated to cash flows). But in practice, this is no easy task.

${ }^{16}$ This result is robust to the sample period and whether returns are expressed in excess or real terms.
} 
valuation). The implied equity discount rate (or expected return to holding stocks) is used to forecast stock returns, the rent/price ratio forecasts returns to housing, the credit spread is used to forecast excess credit returns, and the gap between long term Treasury yields and long-term nominal GDP growth forecasts is used to forecast excess Treasury returns (see Annex 2 for details). In each asset class, valuations appear to have only modest explanatory power over one year returns (i.e. asset returns are relatively noisy in the short-run), but an increasing degree of explanatory power as the investment holding period extends out to a multi-year basis. ${ }^{17}$ Of greater consequence is that in the years preceding the three largest crashes in history for each of the major asset classes, ${ }^{18}$ risk premiums (required returns) declined to unusually low levels - around 1 to 2 standard deviations below the long-term average (Figure 5 and 6). Following a bust, they rapidly reverted back to more normal levels over the next two years. Notably, each of these busts were followed by recessions - on average, six months after a peak in the case of equities, eight months for housing, and around two years for credit and Treasuries (Figure 7). In sum, these results suggest that periods of unusually stretched valuations should feature prominently on the policy making radar.

\footnotetext{
${ }^{17}$ For reasons of data availability, only the results for U.S. asset classes are reported here to demonstrate the concept. Based on the shorter (post-1989) cross-country sample using survey based expectations of long-term growth and inflation, the average $\mathrm{R}^{2}$ (from regressions of realized returns on model-based expected returns) over a one-year holding period for stocks was 0.11 , and 0.18 for bonds. Note that this exercise attempts only to examine the empirical features of standard valuation-based return forecasting models - it is not trying to find an 'optimal' valuation model per-se.

${ }^{18}$ For the purposes of this exercise, crashes were defined as the largest decline in real (equity and housing) or excess (credit and Treasury) total return terms, measured over a three-year observation window (rolling monthly). In order to distinguish separate crash episodes, a new regime is signified whenever the three-year change crosses zero (the series is stationary). Figures are based on the largest three crash episodes, except for housing, which experienced only two episodes of negative three-year real returns between 1953 and 2013.
} 
Figure 4. Valuation-based Asset Return Predictability ( $R^{2}$ across different investment holding periods, 1953-2013)

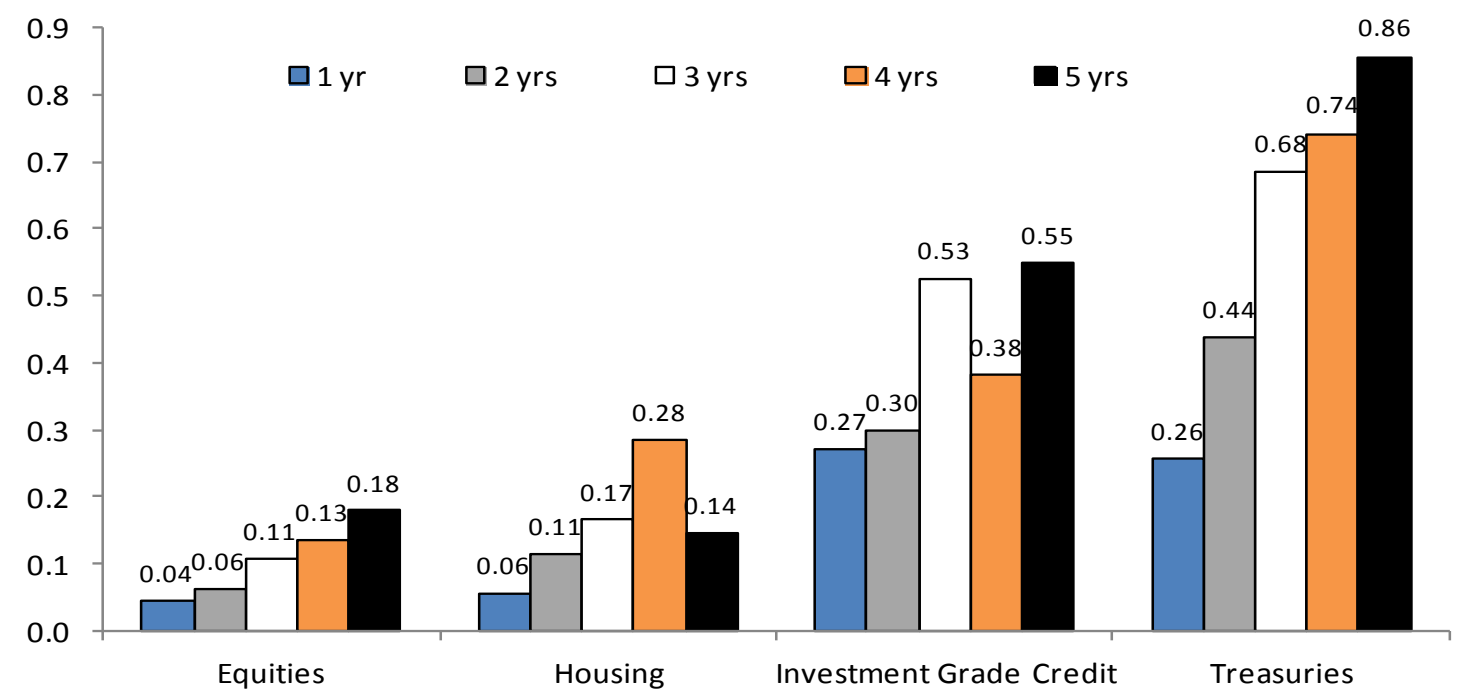

Source: Author's estimates, Haver, Bloomberg

Notes: Chart depicts the $\mathrm{R}^{2}$ from regressions of real (equities and housing) or excess (credit and treasury) returns (measured across different holding periods) on the starting level of valuations for each asset class. Regressions are based on nonoverlapping holding periods over the 1953-2013 sample. In the case of stocks, real returns are regressed on the marketimplied real equity discount rate; in the case of housing, real returns are regressed on the rent/price ratio; for investment grade credit, excess returns on BBB credit are regressed on BBB spreads over duration-matched Treasuries; and for Treasuries, 5 year bond returns 5 years forward are regressed on the 'Wicksellian' risk premium, measured as the $5 y 5 y$ rate less the $5 y 5 y$ forward consensus estimate of growth and inflation. See Annex 2 for more details on the construction of valuation measures.

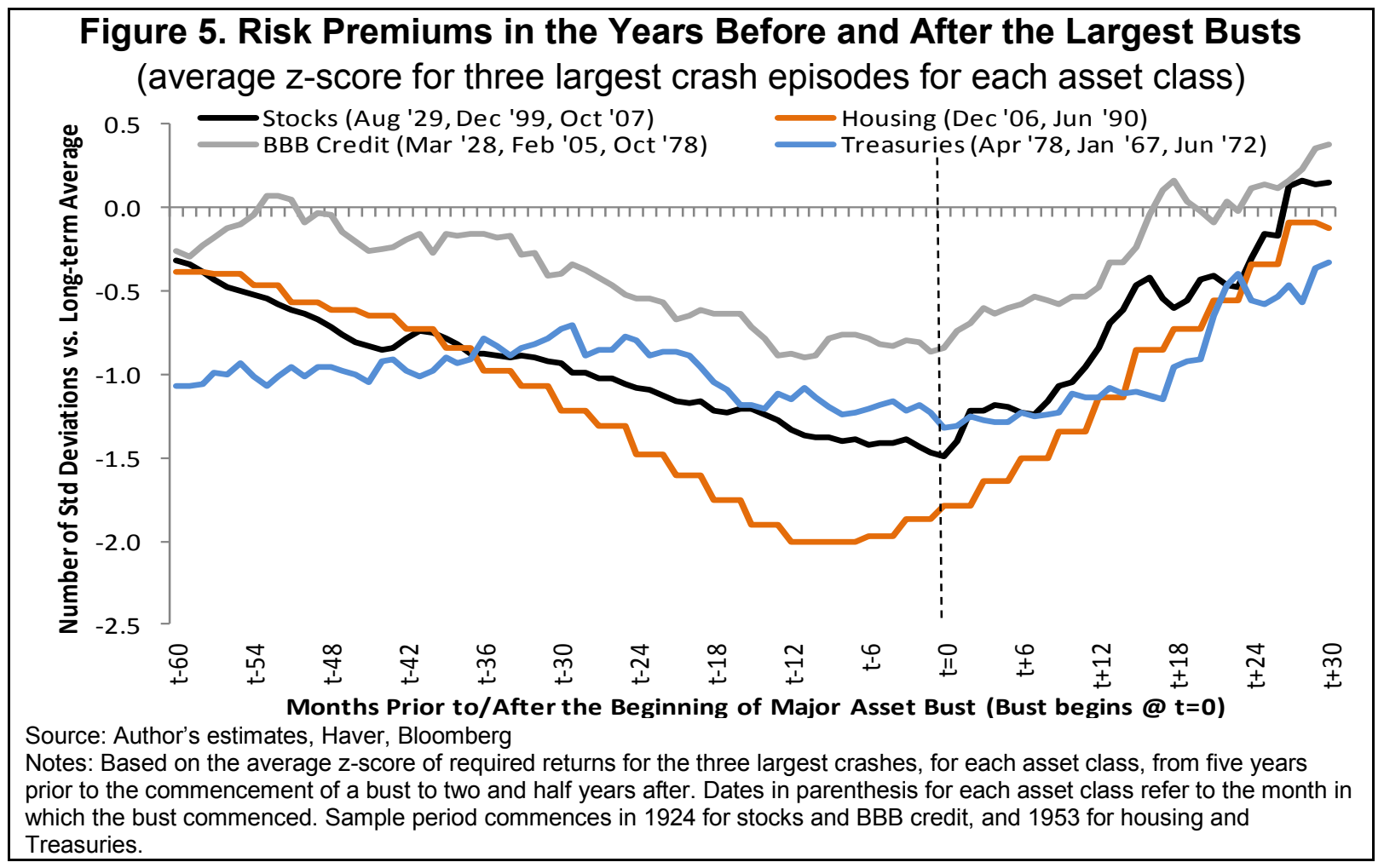




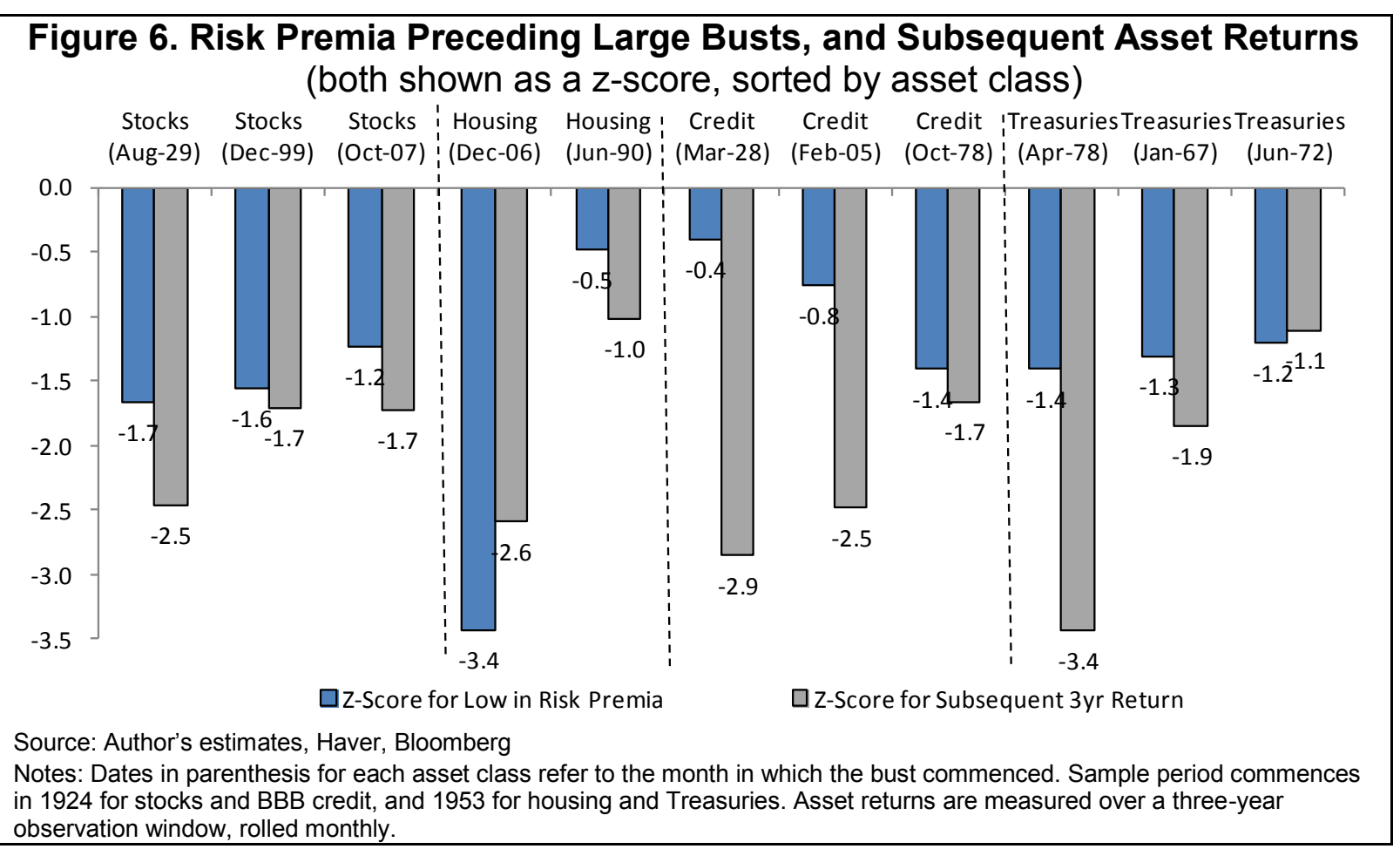

Figure 7. Lead Time between Start of Asset Bust and Onset of Recession (in months, sorted by asset class)

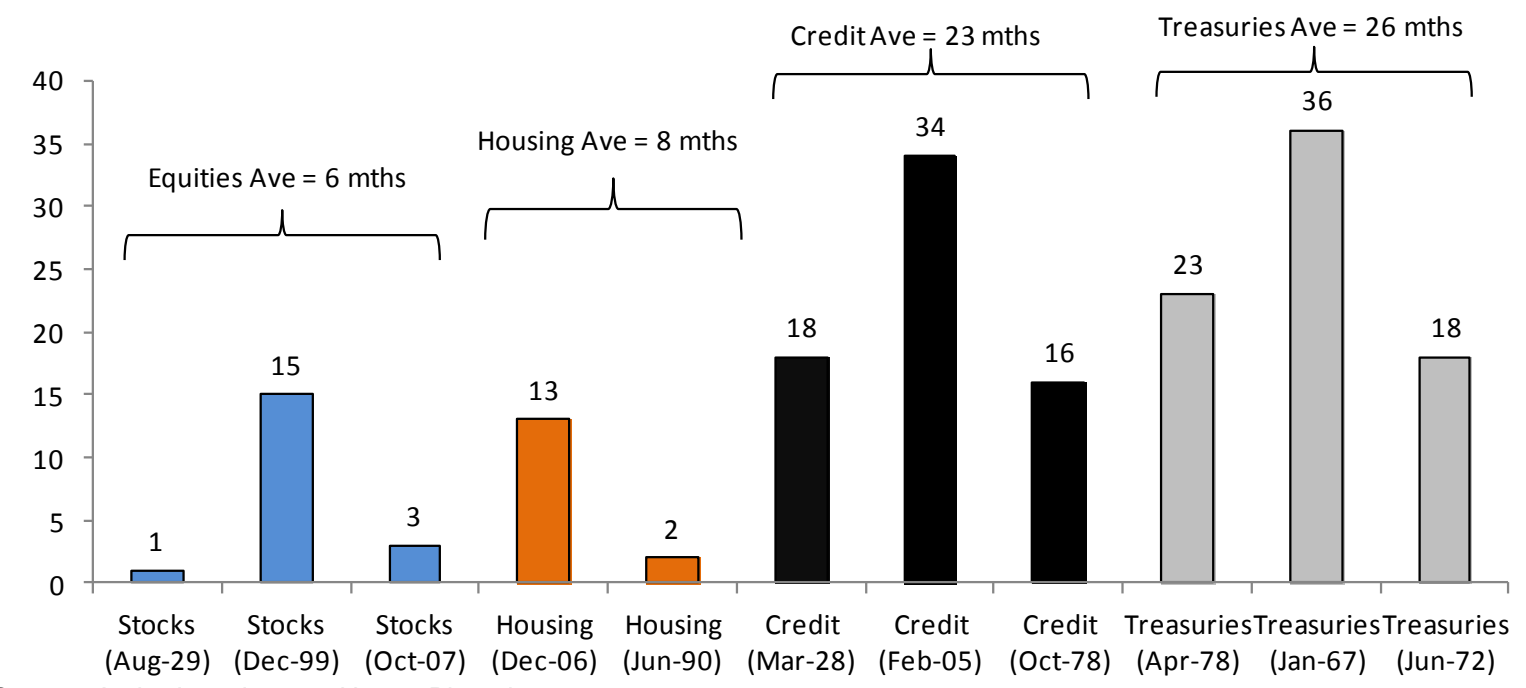

Source: Author's estimates, Haver, Bloomberg

Notes: Dates in parenthesis for each asset class refer to the month in which the bust commenced. Sample period commences in 1924 for stocks and BBB credit, and 1953 for housing and Treasuries. Recession dating is based on the NBER classification.

An assessment of the current state of financial asset valuations is presented in Figures 8-14. Four broad patterns are particularly noteworthy: 
- First, there appears little evidence of a synchronized valuation bubble across world equity markets (Figure 8 and 9). In a sample of 15 developed and 10 emerging markets over the past 25 years, the market-implied real cost of equity (i.e. the required return to hold stocks) seems broadly in line with historical norms, and importantly, is considerably above levels that preceded large busts in the late 1990s and mid-2000s. ${ }^{19}$

- Second, long-term sovereign bond yields are unusually low relative to long-term expectations of real growth and inflation (Figure 10). A sample of 15 developed and 9 emerging markets over the past 25 years show that the average 'Wicksellian' bond risk premium ${ }^{20}$ (measured as the 5 year rate, 5 years forward, minus consensus estimates for growth and inflation over the same period) is around half a standard deviation below average (Figure 10). Of the 24 countries examined, 18 have bond risk premiums that are below their historical average (Figure 11).

- Third, an unusual feature of the current cycle is that the return required by investors to hold each major U.S. asset class is simultaneously below average (Figure 12). While no single asset class appears egregiously stretched on a valuation basis (i.e. close to two standard deviations from historical norms), this situation has occurred for just 5 percent of the post-1953 sample (Figure 13).

- Finally, the asset class that appears most stretched relative to fundamental anchors (and its own history) is low grade U.S. corporate bonds. ${ }^{21}$ Of particular note is that within high yield securities, pricing is now most aggressive at the bottom of the capital structure (Figure 14). While virtually all grades of U.S. credit are trading at below average spreads, it bears mentioning that single-B and triple- $\mathrm{C}$ rated corporate bonds also have spread cushions that would be entirely wiped out in the event of an average default cycle (blue line) over the next five years.

\footnotetext{
${ }^{19}$ Proxies for the equity risk premium provide a similar message. I report results here for the market-implied cost of equity rather than the equity risk premium for two reasons: (i) the cost of equity is a superior forecaster of future stock returns than the equity risk premium; and (ii) stocks are a perpetuity with a duration that is constantly in flux, meaning that deflating the cost of equity by a bond yield at one point in the curve could be akin to comparing apples with oranges.

${ }^{20}$ A negative 'Wicksellian' bond risk premium suggests bond yields are too low relative to the neutral rate for the economy, as proxied by long-run estimates of growth and inflation. By examining the relationship in longterm forward space, the impact of near-term monetary policy settings is ameliorated.

${ }^{21}$ The absence of lengthy default histories for non-U.S. corporate bonds preclude a similar cross-country analysis of credit markets.
} 

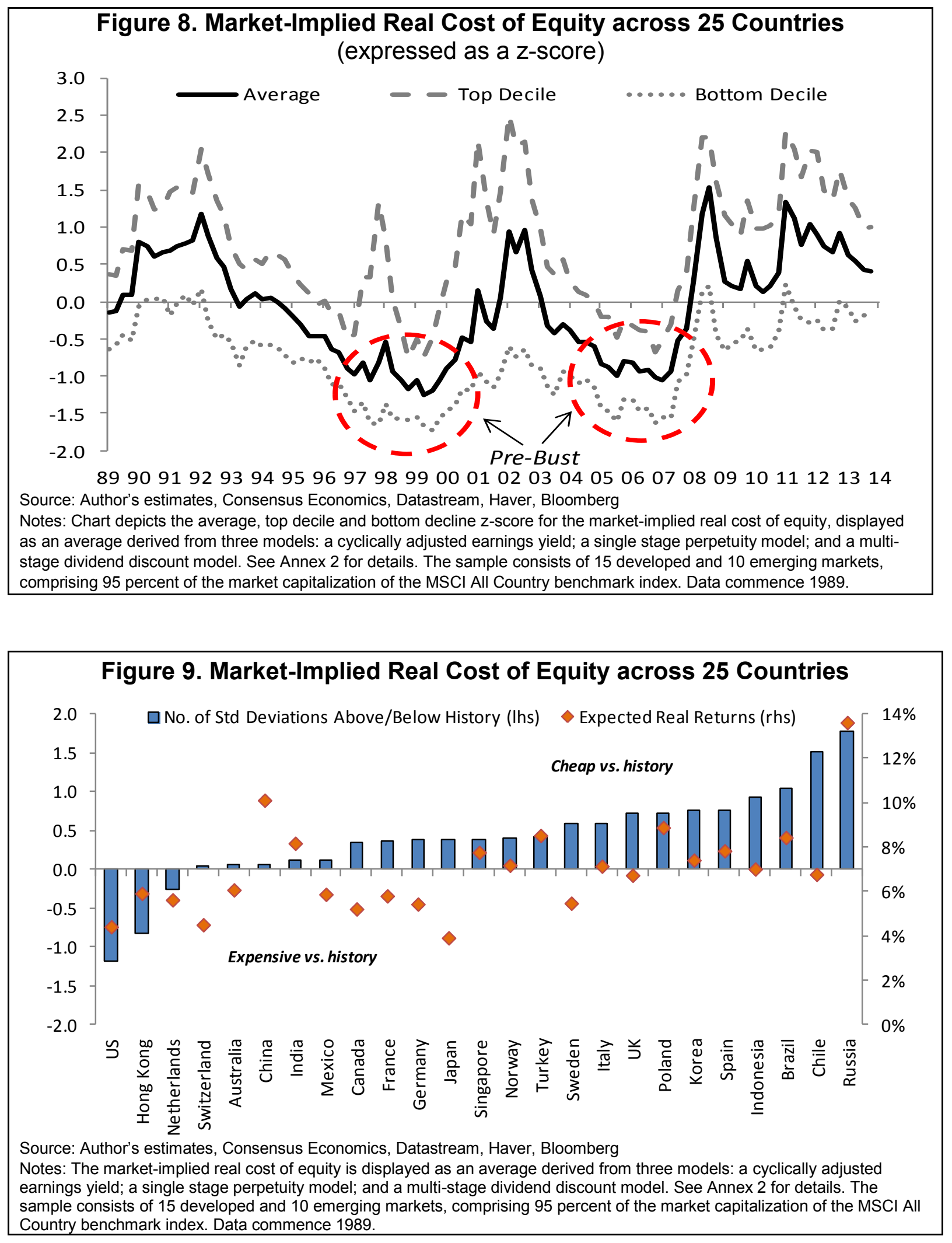
Figure 10. 'Wicksellian' Sovereign Bond Risk Premia across 24 Countries

(5y5y bond yields less 5y5y expectations of real GDP growth and inflation, expressed as a z-score)

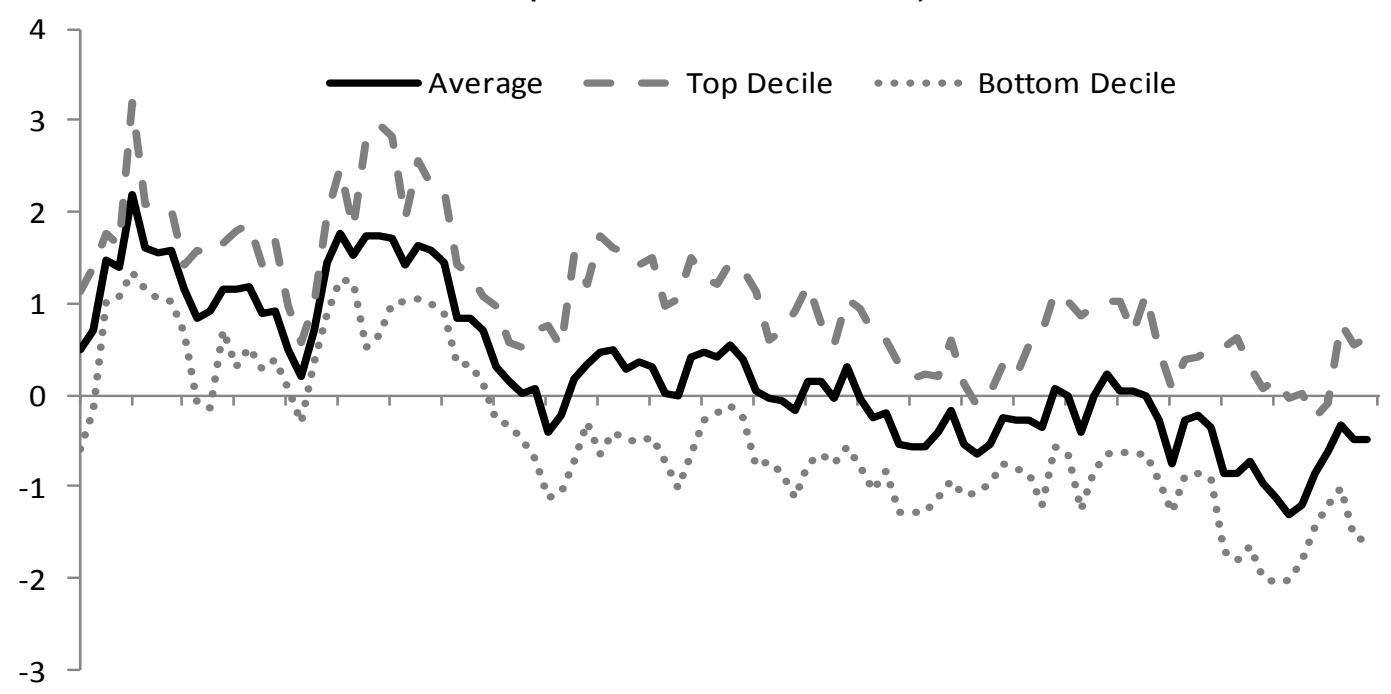

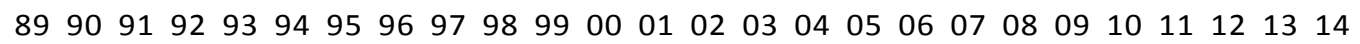
Source: Author's estimates, Consensus Economics, Datastream, Haver, Bloomberg

Notes: Chart depicts the average, top decile and bottom decline z-score for the 'Wicksellian' bond risk premia, measured as the 5 year rate, 5 years forward, minus consensus estimates for growth and inflation over the same period. The sample includes 15 developed markets and 9 emerging markets, comprising 94 percent of the market capitalization of the Citigroup World Government bond benchmark index. Data sample begins 1989.

Figure 11. 'Wicksellian' Sovereign Bond Risk Premia across 24 Countries (5y5y bond yields less 5y5y expectations of real GDP growth and inflation)

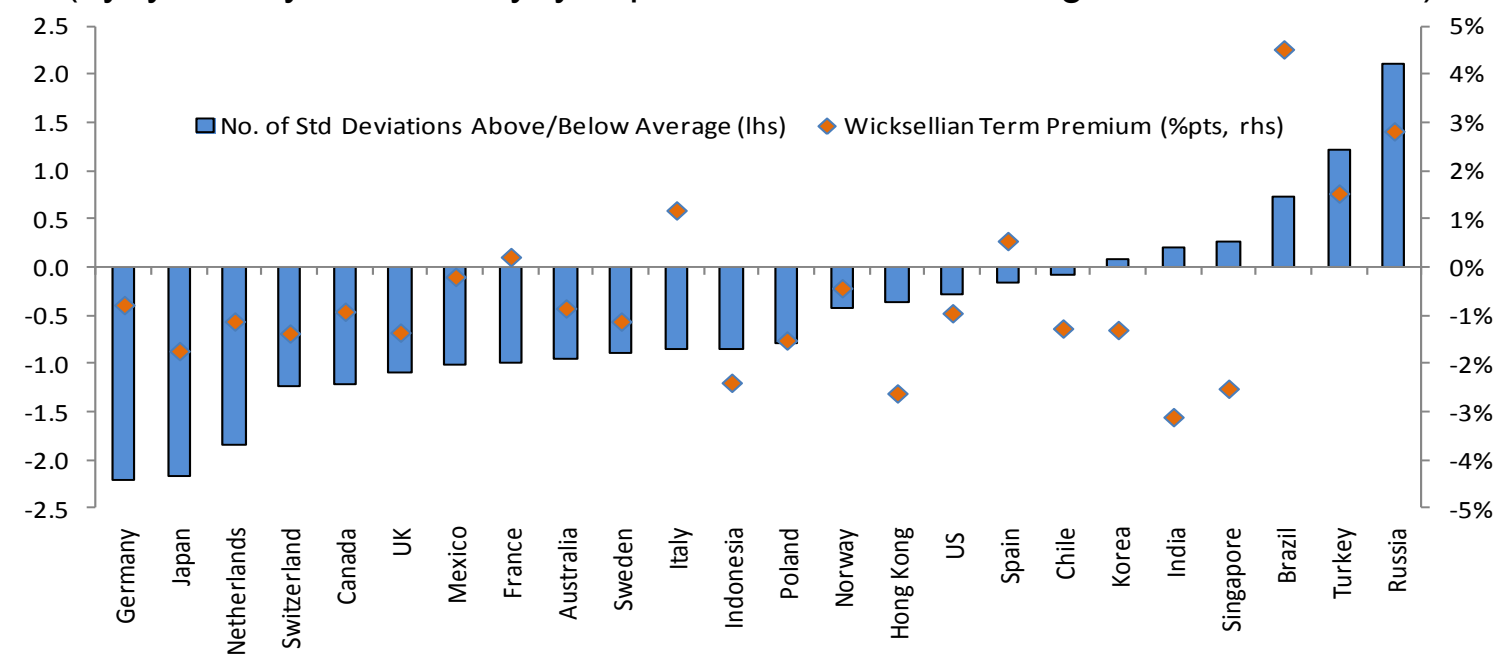

Source: Author's estimates, Consensus Economics, Datastream, Haver, Bloomberg

Notes: Chart depicts the 'Wicksellian' bond risk permia, measured as the 5 year rate, 5 years forward, minus consensus estimates for growth and inflation over the same period. The sample includes 15 developed markets and 9 emerging markets, comprising 94 percent of the market capitalization of the Citigroup World Government bond benchmark index. Data sample begins 1989. 


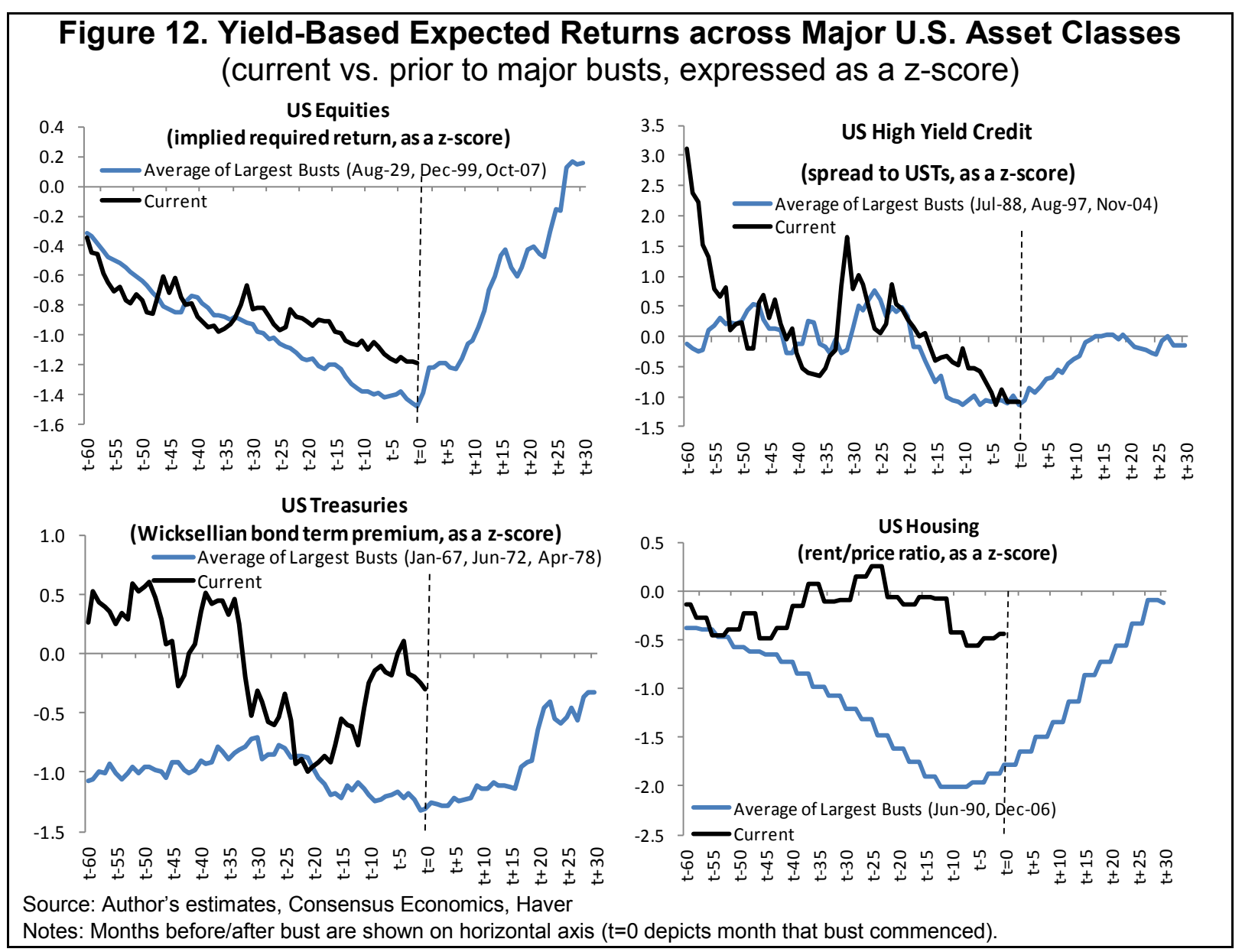

Figure 13. Average Expected Return across Major U.S. Asset Classes (average Z-score across asset classes)

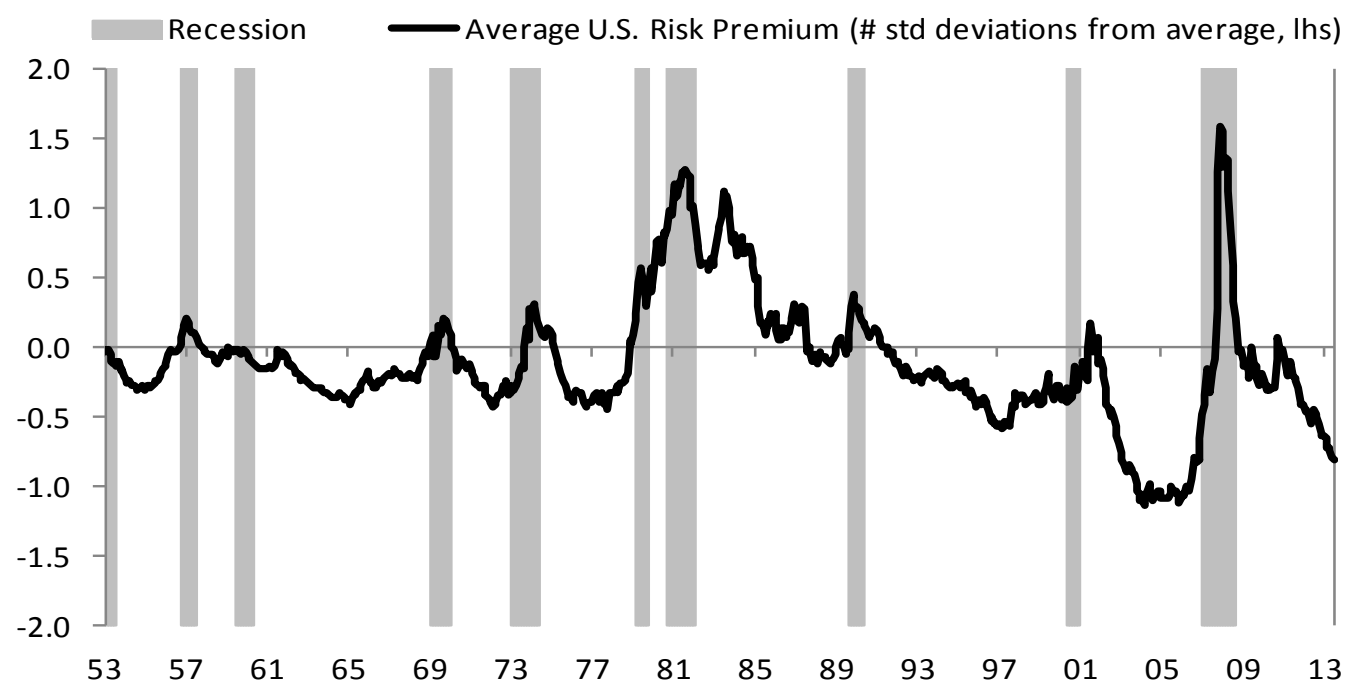

Source: Author's estimates, Consensus Economics, Datastream, Haver, Bloomberg

Notes: Includes U.S. equities, housing, BBB-rated credit, high yield credit, and Treasuries. Valuation measures are defined in Annex 2. 


\section{Figure 14. U.S. High Yield Securities}

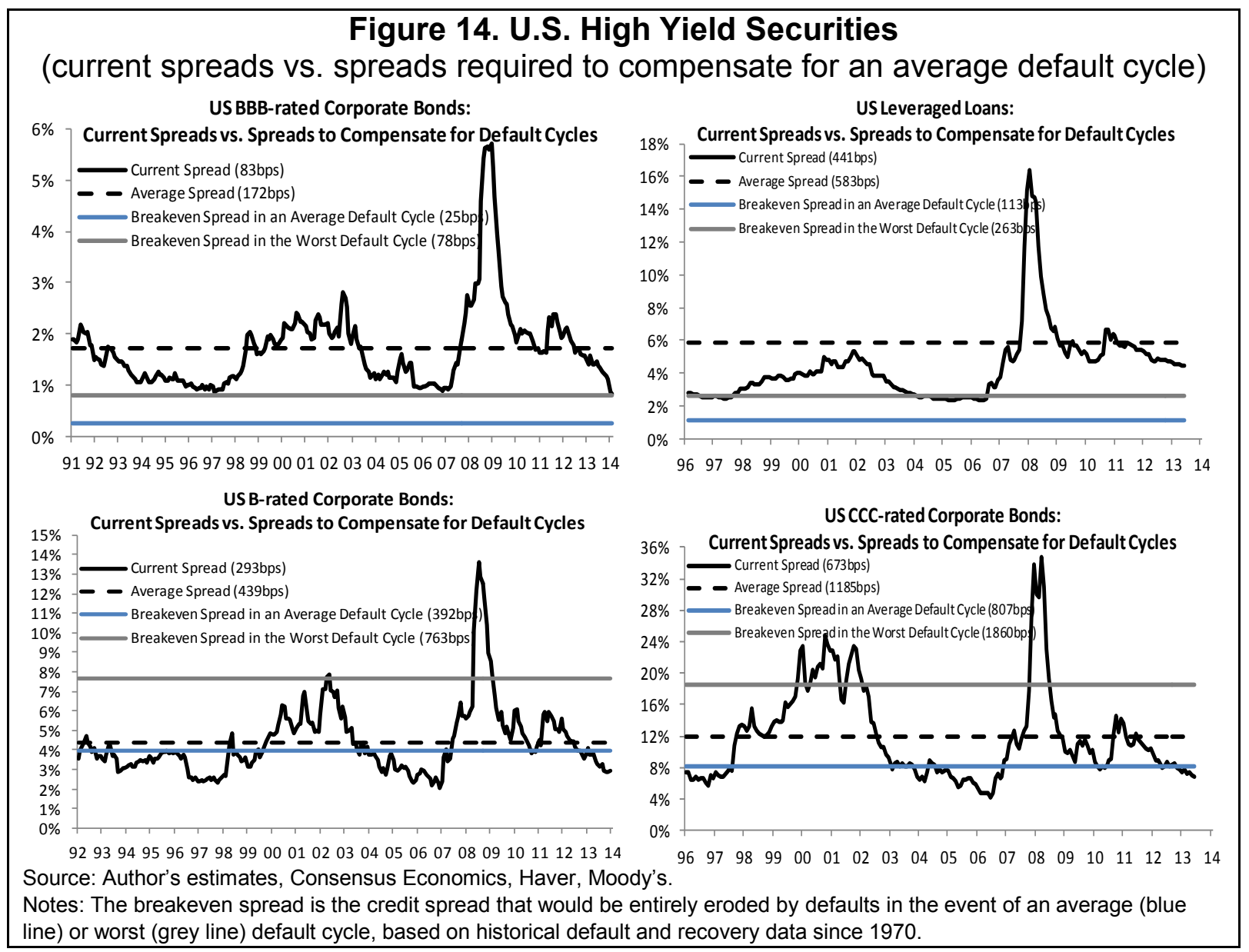

\section{B. The Quantities Pillar}

Though asset pricing models comprise a key component of the surveillance toolkit, risk taking behavior, and financial vulnerabilities more generally, might also be reflected in subtler, non-price terms - beyond what asset valuations alone can signify. Additionally, 'top down' asset pricing models are subject to considerable estimation error: forward looking inputs are unobservable and small changes in discount rates for long duration assets can exert a very large impact on estimates of fair value (Figure 1). As such, (non-price) quantity data 
may have a useful cross-referencing role for the purposes of financial surveillance. ${ }^{22}$ Against this backdrop, the analysis that follows is based on the 'bottom up' information content in: (i) the quantity and quality of capital market issuance; (ii) trading volumes; (iii) investor fund flows; and (iv) investor surveys. This may be the first proposal for a multi-faceted cross-asset 'quantities pillar' to be employed as a supplement to more traditional valuation-based surveillance analysis. ${ }^{23}$

\section{(i) Quantity and Composition of Capital Market Issuance}

The financial crisis of 2008 yielded important insights regarding the information content embedded in the increasing quantity and declining quality of capital market issuance. Credit markets are particularly amenable to scrutiny in non-price terms as implicit leverage, subordination, illiquidity, and a paucity of investor protection features allow investors to take on risk in ways that might transcend conventional measurement through spreads alone. Issuance patterns in the structured credit and asset-backed security markets underwent profound shifts in the years leading up to global financial crisis, notably in that securitization issuance volumes surged in the most complex, risky, and opaque market segments that had previously played only a peripheral role in the industry (Segoviano and others, 2013). For instance, between 2000 and 2005, annual U.S. subprime mortgage issuance rose from $\$ 100$ billion to more than $\$ 600$ billion, lifting the subprime share of total U.S. mortgage origination from a low of 6.9 percent to a peak of 20.1 percent. ${ }^{24}$ These loans featured heavily in the explosive growth in collateralized debt obligations (CDOs). Over the same period, the rapid emergence of new and federally-unregulated players as a force in U.S. mortgage markets saw private-label residential mortgage backed security (MBS) issuance increase from $\$ 150$ billion to $\$ 1.2$ trillion, increasing their share of total MBS issuance from 18 percent to 56 percent (Figure 15). ${ }^{25}$ Between 2000 and 2007, global issuance of CDOs

\footnotetext{
${ }^{22}$ Traditionally, to the extent that non-price data has been examined in the context of asset bubbles, the focus has been almost exclusively on credit growth, dating back to at least Kindleberger (1978) and Minsky (1986, 1992). Yet credit growth can occur in ways that escape conventional measurement (especially in shadow banking), and moreover, bubbles might still present a major threat to financial stability even in the absence of leverage, particularly where their bursting drives risk premiums out to unusually wide levels that prohibit capital formation.

${ }^{23}$ Related analysis of both price and quantity-based data appear in BIS (2012) and IMF (2014). In a more limited context, Stein (2013) examines the financial stability implications derived from patterns in credit issuance, while Feroli and others (2014) focus on investor fund flows.

${ }^{24}$ A good portion of these were adjustable-rate mortgages, usually starting with a two- or three-year fixed-rate period and deferral of principal repayment up to five years, which meant that borrowers were heavily exposed to upward interest rate and principal payment shocks at the time of reset.

${ }^{25}$ U.S. Home Mortgage Disclosure Act data show that in 2006 more than 45 percent of high cost first-time mortgages were originated by independent mortgage companies - institutions that were not regulated by federal banking agencies and that sold virtually all of the mortgages they originated (Bernanke, 2008).
}

(continued...) 
increased more than six times to $\$ 1$ trillion, while issuance of CDO-squared product increased eleven-fold to $\$ 300$ billion. ${ }^{26}$ Far from reflecting just a U.S. phenomena, between 2000 and the onset of the crisis, annual European securitization issuance increased from $€ 80$ billion to just over $€ 700$ billion. Other relatively obscure forms of high-risk debt issuance with fewer and fewer investor protection clauses (a process known as 'covenant creep') increased markedly in both the U.S. and Europe, notably payment-in-kind (PIK) and covenant-lite issuance. ${ }^{27}$

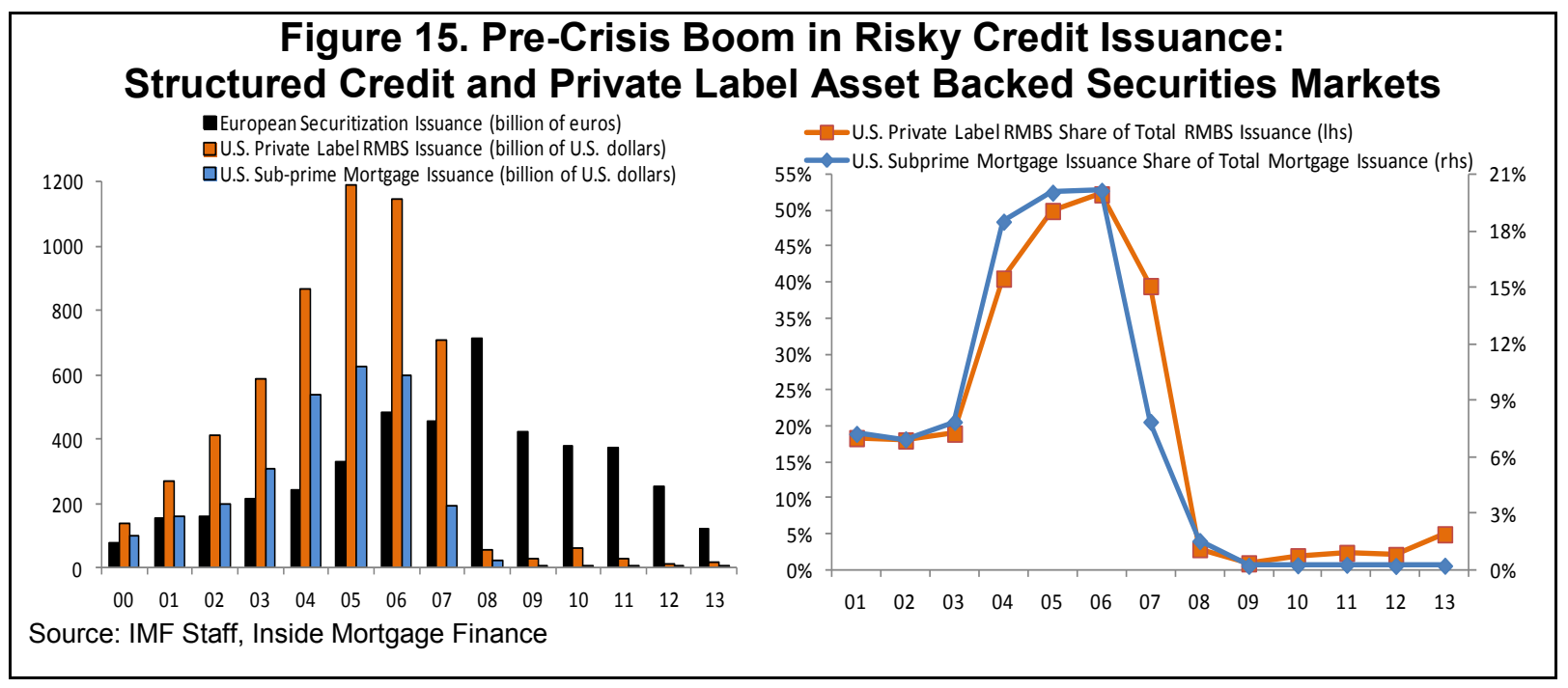

Unusual patterns in the quality and quantity of issuance in debt capital markets have also been shown to offer promise for surveillance purposes outside of just the recent crisis period. In a study of the first high yield credit boom and bust cycle of the 1980s, Kaplan and Stein (1993) describe how the value of leveraged buyouts (LBOs) grew dramatically from just under \$1 billion in 1980 to over \$60 billion in 1988 (before collapsing below \$20 billion in the credit market bust of the following year). This growth was fuelled in part by the introduction of deferred or payment-in-kind interest features in high-yield bonds, which further reduced the protection of already junior creditors and was analogous to investors willingly accepting low or even negative ex-ante risk premia. Similarly, based on data stretching back to the 1920s, Greenwood and Hanson (2013) establish that compositional shifts in the pattern of debt issuance between high and low quality firms, including the high yield share of total nonfinancial debt issuance, have had strong predictive power over future

\footnotetext{
${ }^{26}$ In a CDO-squared, the underlying reference pool is an existing CDO.

${ }^{27}$ PIK securities are a financial instrument that pay interest to investors in the form of additional debt or equity instead of a cash coupon. They are attractive to companies who need (or prefer) to avoid making cash outlays to investors. Cove-lite issuance refers to debt obligations which do not contain the usual protective covenants for the benefit of the lending party.
} 
corporate bond returns (exceeding the explanatory power of spreads alone). A high and/or rising share of debt market issuance from lower quality firms can portend sharp credit spread widening episodes (Figure 16). As lower quality firms face binding financing constraints (unlike higher quality peers, they do not enjoy an indefinitely open window to raise capital), a relative flurry of lower quality debt issuance can signify unusually easy financing conditions and thus should be interpreted as an inherently procyclical development (Korajczyk and Levy, 2003). A similar result holds for the debt and equity raisings conducted by relatively small firms (Covas and den Hann, 2006). The implication is that policy makers need to go beyond simply monitoring the level of credit spreads or the growth in aggregate credit - the composition and quality of credit issuance may be even more important.

\section{Figure 16. High Yield Share of Credit Issuance Before/After Credit Blow-ups}

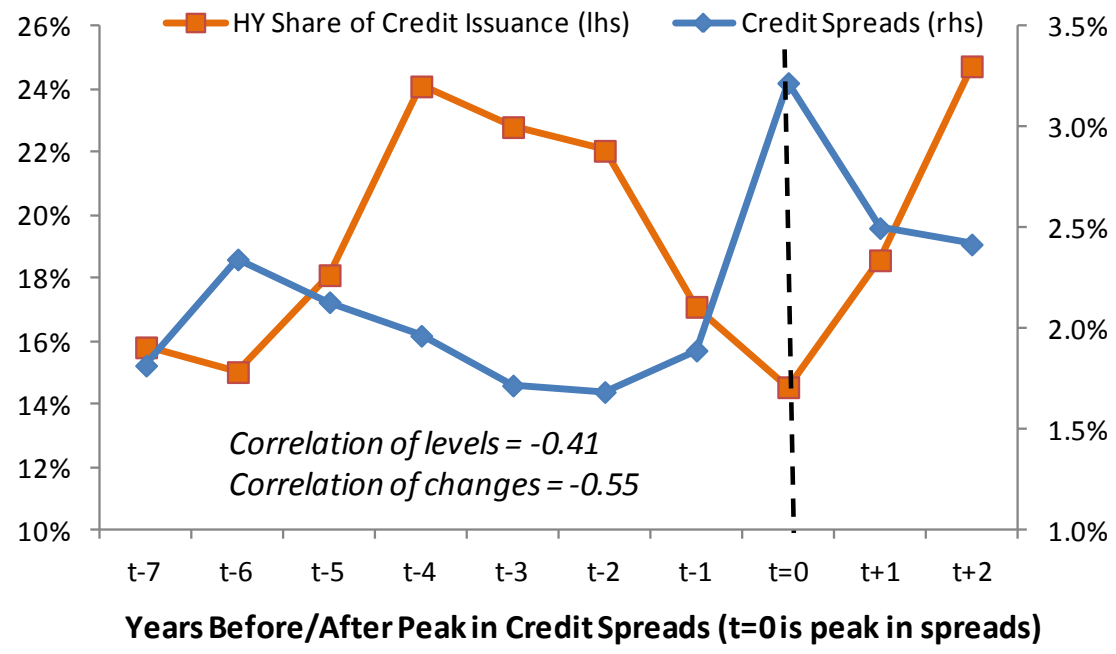

Source: Author's estimates, Greenwood and Hanson (2013)

Notes: Figures are based on an average of the ten largest annual BBB spread widening episodes since 1924.

Drawing on the pecking order theory of Myers and Majluf (1984) where corporate managers ('insiders') exploit their informational advantages (in that they know more about the value of their firms than outsiders), patterns of equity issuance that accelerate into a large run up in stock valuations can also be of interest for financial surveillance purposes. Bernstein and Arnott (2003) show that the two largest booms (and busts) in U.S. stock market history-the late 1920s and late 1990s-coincided with the fastest ever rates of aggregate U.S. net equity issuance. ${ }^{28}$ Nelson (1999) finds each percentage point of U.S. net share issuance is associated with a market that is 5 percent overvalued relative to historical averages. At the single stock level, inflated valuations have been found to be a key element of IPOs which helps to explain their subsequent long-run underperformance (Ritter, 1991; Schultz, 2003,

\footnotetext{
${ }^{28}$ The trend pace of net dilution was 5 percent in the late $1920 \mathrm{~s}$, and 3 percent of market capitalization in the late 1990s. The cyclically-adjusted price-earnings multiple peaked at 33 times and 47 times respectively.
} 
Baker and Xuan, 2009) ${ }^{29}$ Since stock prices are positively correlated, and all firms are incentivized to issue equity when valuations are high, aggregate equity issues tend to cluster around market peaks (Korajczyk and others, 1990; Baker and Wurgler, 2000). Gilchrist and others (2004) show that as stock prices move well above measures of fundamental value, managers rationally respond by issuing new equity which has the effect of reducing the cost of capital and increasing the desire to invest. ${ }^{30}$ The corporate investment boom in the U.S. accompanying the late 1990 s equity market bubble is a notable recent example. ${ }^{31}$

Based on U.S. data since 1965, Figure 17 illustrates the empirical link between an unusually low cost of capital, and elevated net equity issuance (gross issuance less gross buybacks) the following year. ${ }^{32}$ Drawing on the experience of the largest stock booms in the U.S., Germany, China and India, Figure 18 similarly shows that initial public offering (IPO) volumes tend to surge when the cost of raising capital (i.e. the required return for investors to hold stock) is unusually low. Both of these observations reflect the notion that corporate managers are incentivized to issue securities when prices are unusually high relative to fundamentals.

\footnotetext{
${ }^{29}$ Earnings manipulation has also been found to contribute to procyclical issuance at the single-stock level: companies issuing new stock tend to enjoy particularly good earnings and stock price performance prior to an offering, as earnings are managed upwards by incorporating all possible accruals into income. However the accelerating recognition of income simply borrows from the future. Investors fall into the frequent trap of extrapolating the good times to last indefinitely, only to be greeted with a sharp subsequent drop off in stock price performance (Loughran and Ritter, 1995, 1997; Teoh and others, 1998).

${ }^{30}$ Neoclassical investment theories such as 'Tobin's Q' posit a direct, simple link between market valuation and investment decisions: firms invest when the increase in market value due to investment exceeds the costs.

${ }^{31}$ From 1992 to 2000, the non-residential investment share of GDP rose from 8.5 to 13.2 percent (a record).

${ }^{32}$ Note that capital raisings occurring during or just after recessions - when valuations tend to be relatively depressed - are not of interest for the purposes of bubble surveillance. These are not voluntary in the sense that corporate managers seek to exploit stretched valuations.
} 
Figure 17. U.S. Aggregate Net Equity Issuance vs. Equity Valuations

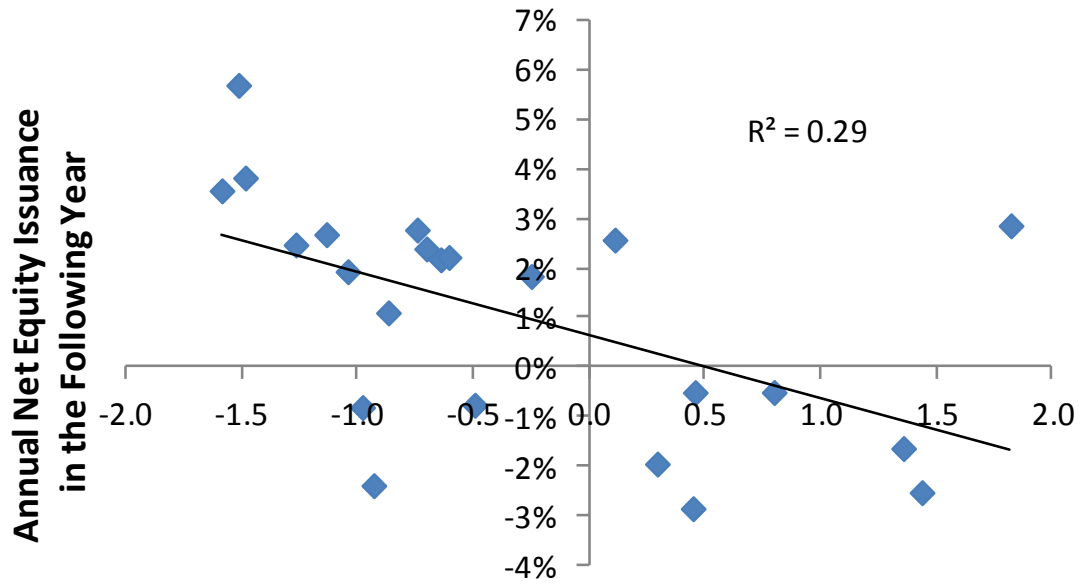

Risk Premia (\# of Std Deviations vs. Average) at end of Year

Source: Author's estimates, Haver

Notes: Annual data based on the S\&P 500 from 1965- 2013. The regression measures the 'voluntary' equity issuance response (i.e. when real returns have been positive over the past five years) of corporate managers to different levels of risk premia (required return) in the stock market. The required return on stocks (an average of three model outputs, as defined in the Annex 2) is a statistically significant predictor (at the 1 percent level) of net equity issuance the following year.

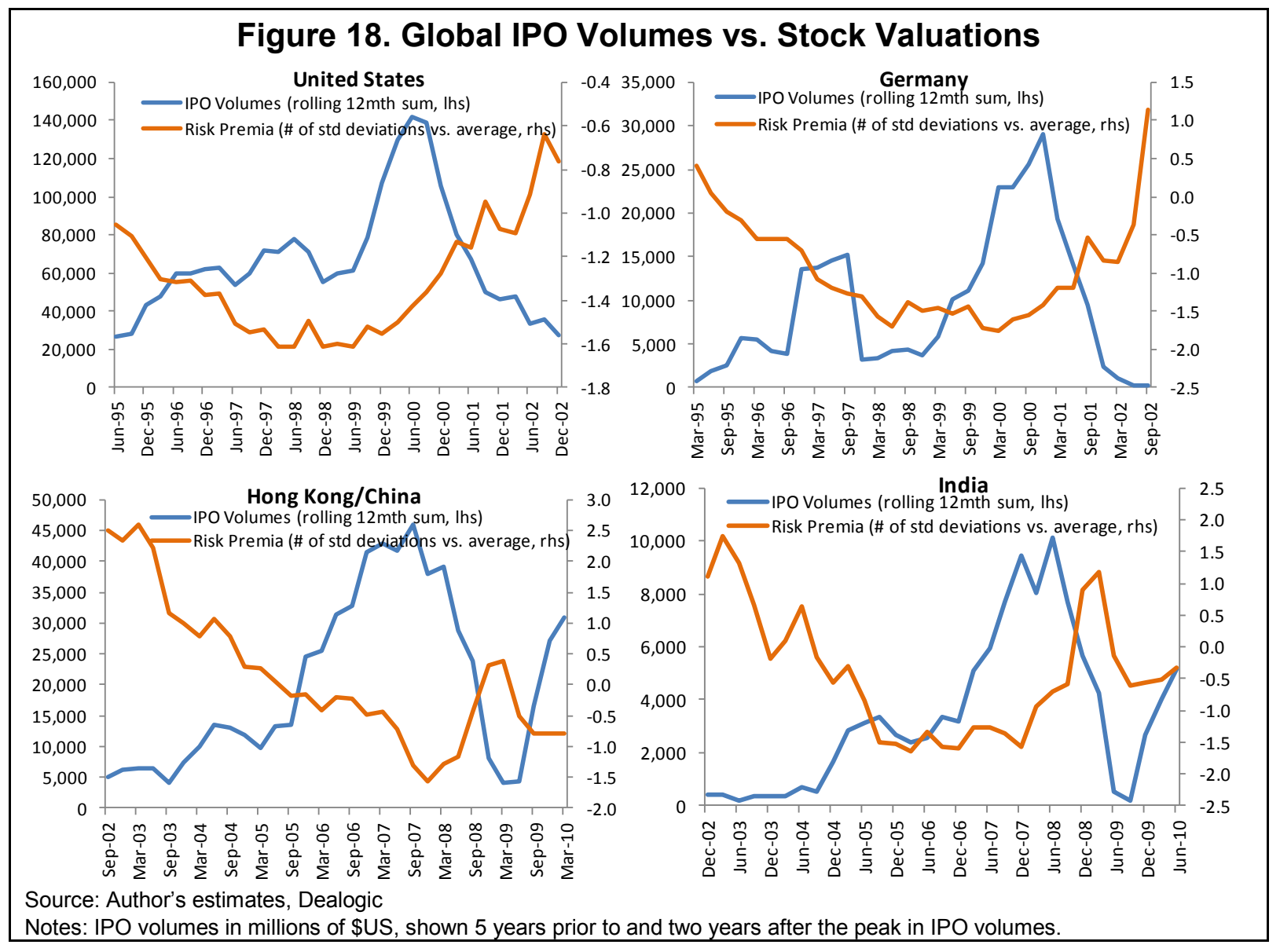


In another illustration of the 'insider selling' concept, private equity management teams have also been found to invest a substantially smaller fraction of their net worth in post-buyout equity vis-à-vis pre-buyout equity: managers tend to "cash out" a large fraction of their prebuyout equity investment at the time of the exiting buyout, and may therefore have an incentive to participate in overpriced exits (Kaplan and Stein, 1993) ${ }^{33}$ Collectively, the procyclical findings on debt and equity issuance suggest a role for policy makers to closely monitor changes in the quantity and composition of capital market financing.

At present, the most troubling patterns of issuance across the capital markets appear to be those at the riskier end of the credit complex. In absolute terms, high yield bond issuance is running at more than double the pace of pre-crisis levels in and outside the U.S. market, and the relative share of high yield issuance is also rising (top panel, Figure 19). Furthermore, U.S. leveraged loan issuance is at new highs in absolute terms and approaching new highs in relative terms, while issuance volumes of leveraged finance securities in Europe (leveraged loans and high yield) are approaching pre-crisis levels (middle panel, Figure 19). Other signs of rising risk appetite can be found in the marked increase in covenant-lite loans and payment-in-kind notes (bottom panel, Figure 19), both of which afford investors relatively fewer protections compared to conventional fixed income securities. The 'search-for-yield' has also manifested in an opportunistic rebound in sovereign bond issuance by first-time issuers with an average sub-investment grade credit rating - both issuance volumes and the number of new issuers over the past four years has been more than double that recorded in the preceding four years (Figure 20). For equity markets however, issuance trends are less troubling. In contrast to the late 1990s equity bubble, companies in the U.S. continue to buy back stock on aggregate (Figure 21), and global IPO and merger and acquisition activity remain below previous cyclical highs (Figure 22).

\footnotetext{
${ }^{33}$ Kaplan and Stein (1993) also find that ahead of a downturn in company fortunes, financiers with the most intimate knowledge of deals such as relatively risk averse bank lenders and private subordinated debt financiers ('insiders') begin exiting while public subordinated lenders ('outsiders') increase their exposure.
} 


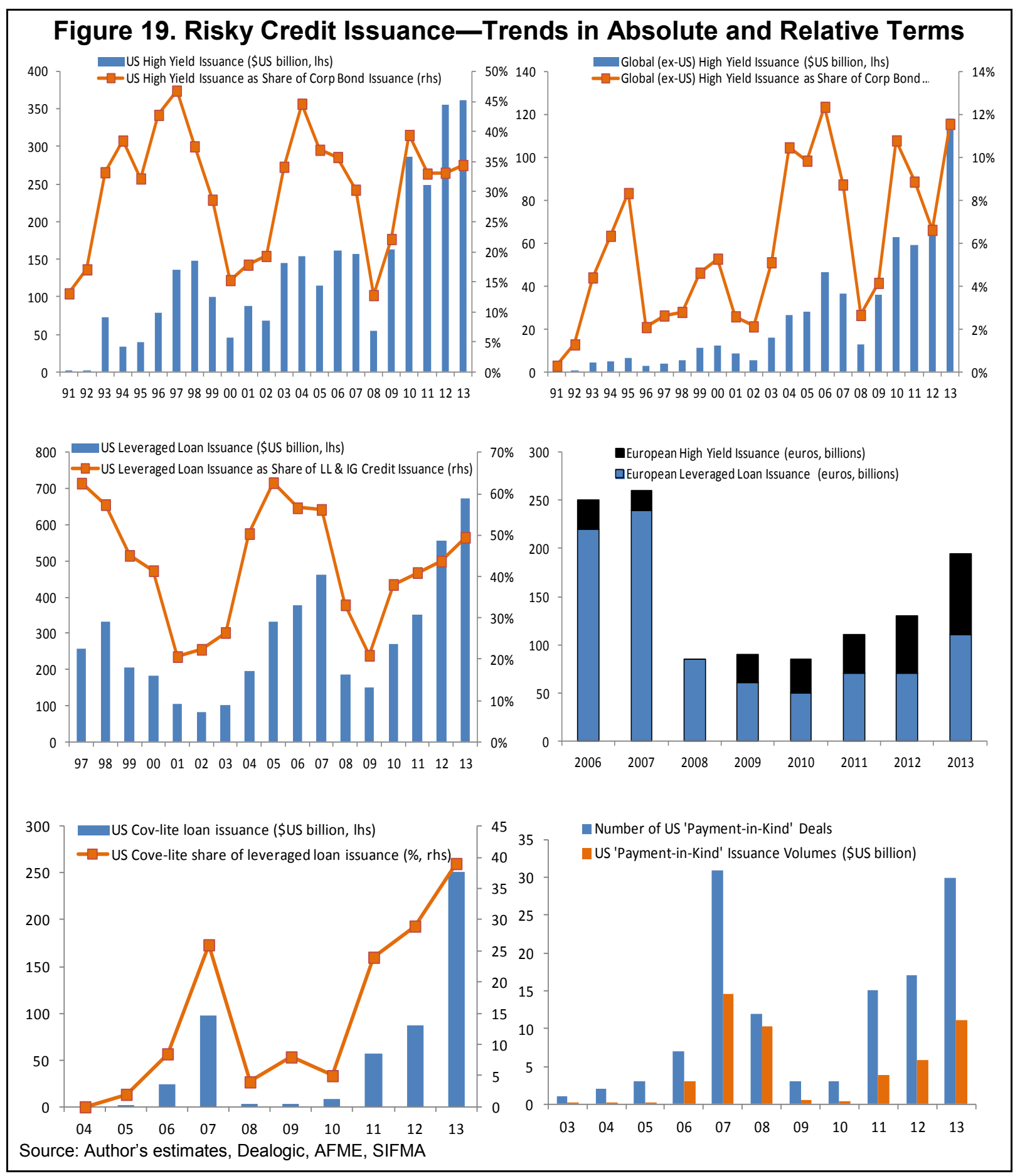


Figure 20. Annual Sovereign Debt Issuance for First Time Issuers

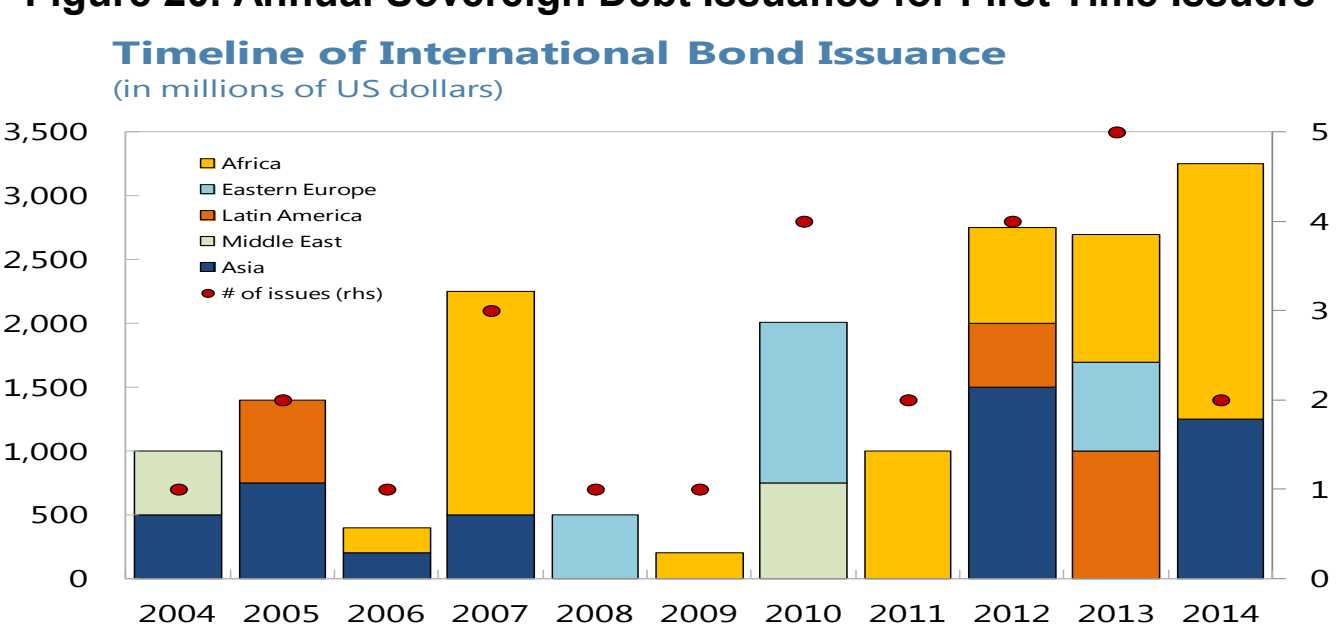

Source: Guscina and others (2014), Deologic

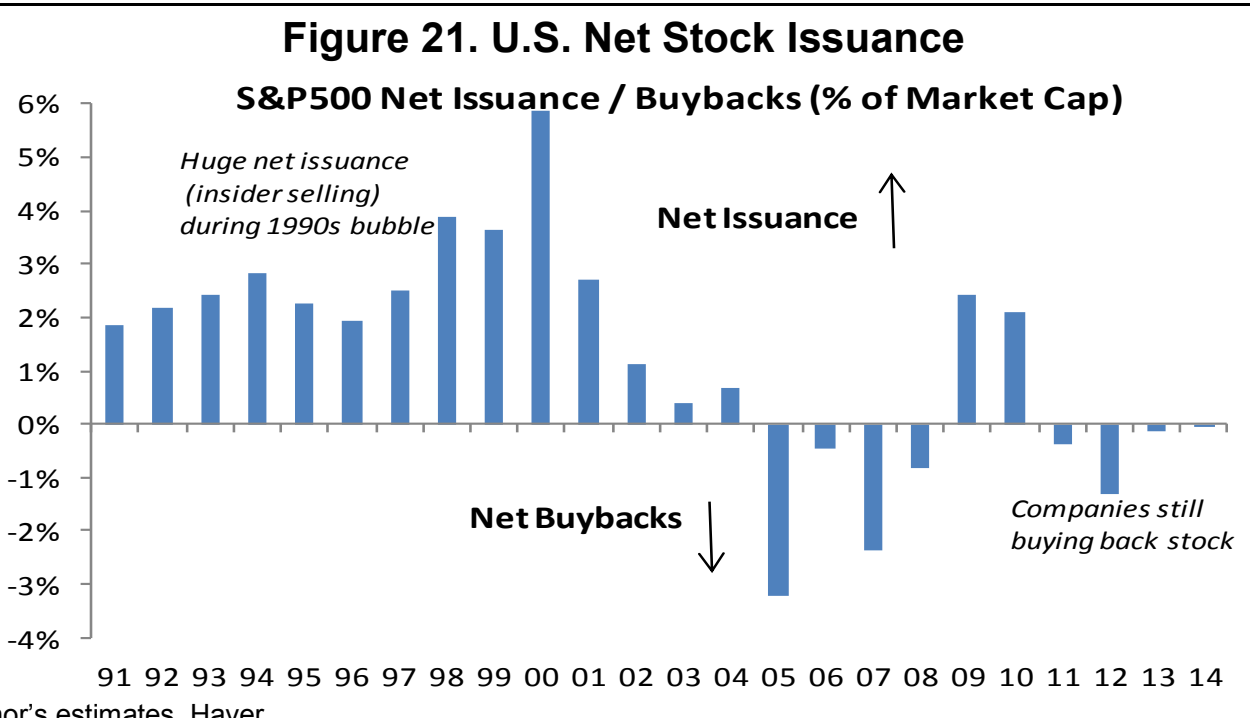

Figure 22. Activity in Worldwide Equity Financing

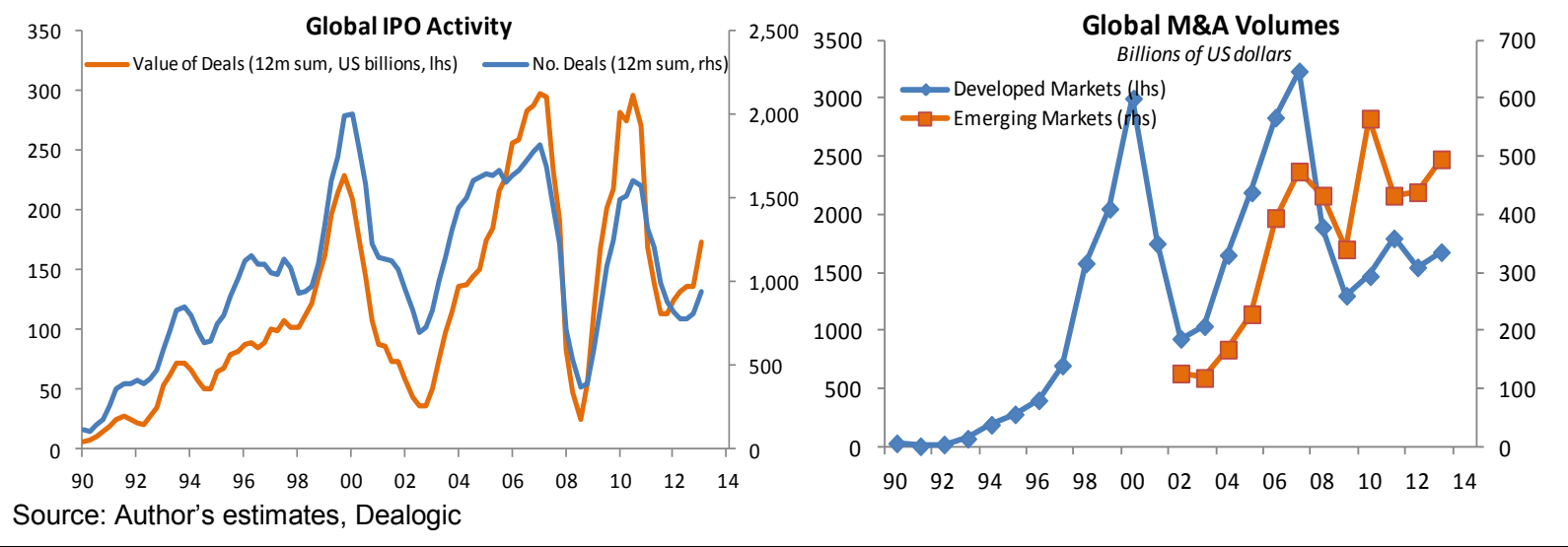

CInternational Monetary Fund. Not for Redistribution 


\section{(ii) Trading/Transaction Volumes}

Periods of unusually elevated trading activity may also have a role to play in surveillance work. Classical asset pricing theory suggests that where investors share the same beliefs and information, and perceive one another to be rational, the incentive to transact (at the expense of one another) would evaporate. As a result, trading activity would collapse to reflect only unanticipated liquidity and portfolio rebalancing needs of investors. However, these motives seem far too small to account for the enormous trading volumes observed in reality, most notably during periods of rapidly rising asset prices. Though trading volume is frequently relegated to a separate and effectively unconnected area of inquiry from studies of market efficiency, it is hard to imagine a fully satisfying asset pricing model - in either the rational or behavioral genres - that does not give a front-and-center role to trading volume (Hong and Stein, 2007). As Cochrane (2011, p. 1079) observes in a sweeping survey, "every asset price bubble - defined by popular use of the label - has coincided with a trading frenzy, from Dutch tulips in 1620 to Miami condos in 2006."34

Figure 23 displays the relationship between the growth in real stock prices and growth in trading volumes across a variety of equity markets during some the largest bull markets in history: the 'Roaring 1920s' episode, Japan's Heisei bubble in the late 1980s, the U.S. technology bubble in the late 1990s, and China's equity boom in the mid-2000s. A similar pattern for transaction volumes unfolded in the case of the recent U.S. housing market bubble (see Figure 2). Average daily trading volumes in the U.S. mortgage backed security market increased five-fold in absolute terms between 2000 and 2008 (and doubled relative to lower risk Treasury and corporate bond markets), while high yield trading activity also rose relative to investment grade credit trading activity prior to the crisis (left hand panel, Figure 24$).^{35}$

\footnotetext{
${ }^{34}$ Kindleberger (2011, p. 15) likens speculative manias to a "frenzied pattern of purchases" reflected in rapidly rising trading volumes, a phenomena synonymous with the 'greater fool theory' whereby more and more euphoric investors purchase securities solely in anticipation of future short-term capital gains. For a related discussion of transaction volumes in the Dutch Tulip Mania, see Mackay (1841) and Garber (2001); for the South Sea stock bubble of 1720, see Carlos, Neal, and Wandschneider (2006); for the U.S. stock bull market of the 1920s, see Thomas and Morgan-Witts (1979) and Hong and Stein (2007); for a similar phenomena during the 1990s technology bubble, see Cochrane (2003) Scheinkman and Xiong (2003); Ofek and Richardson (2003); and Hong and others (2006).

${ }^{35}$ Hong and Sraer (2013) document "quiet bubbles" as a phenomena unique to high grade debt markets, as bonds have a smaller embedded resale option value than infinite-lived assets like stocks and housing, and hence have less disagreement, volatility, and turnover.
} 
Figure 23. Growth in Equity Trading Volumes Around Real Stock Price Booms (average across 24 countries)

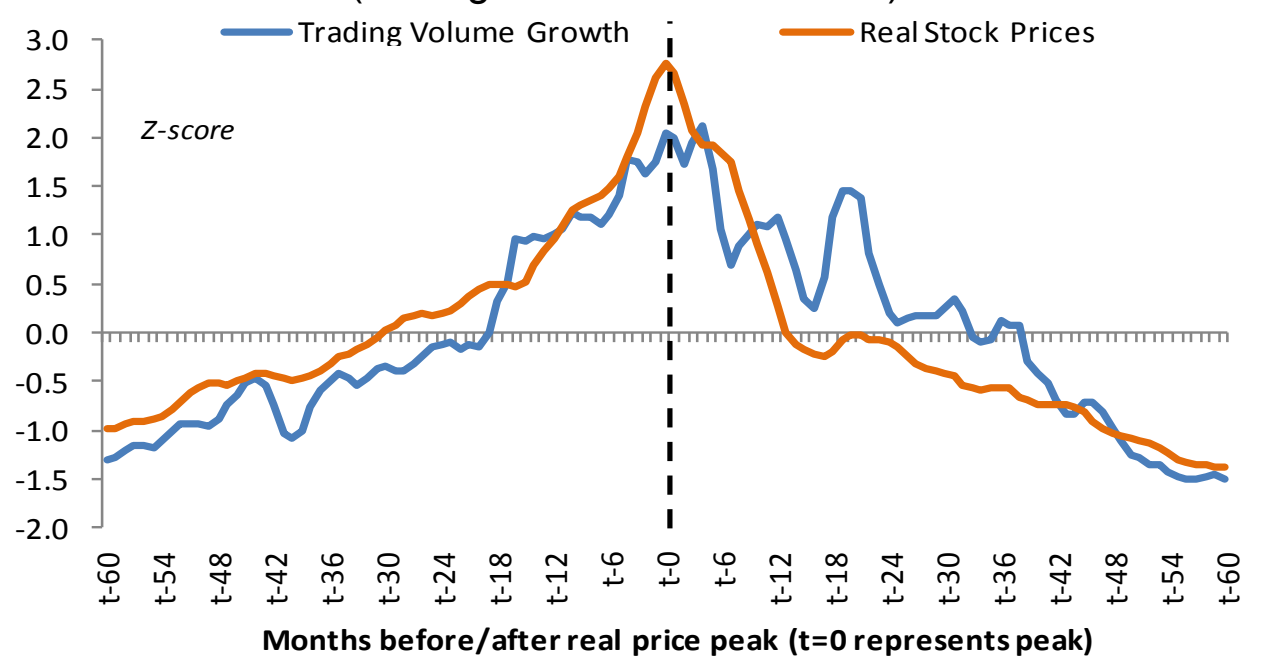

United States, 1924 - 1934

Japan, 1982 - 1992
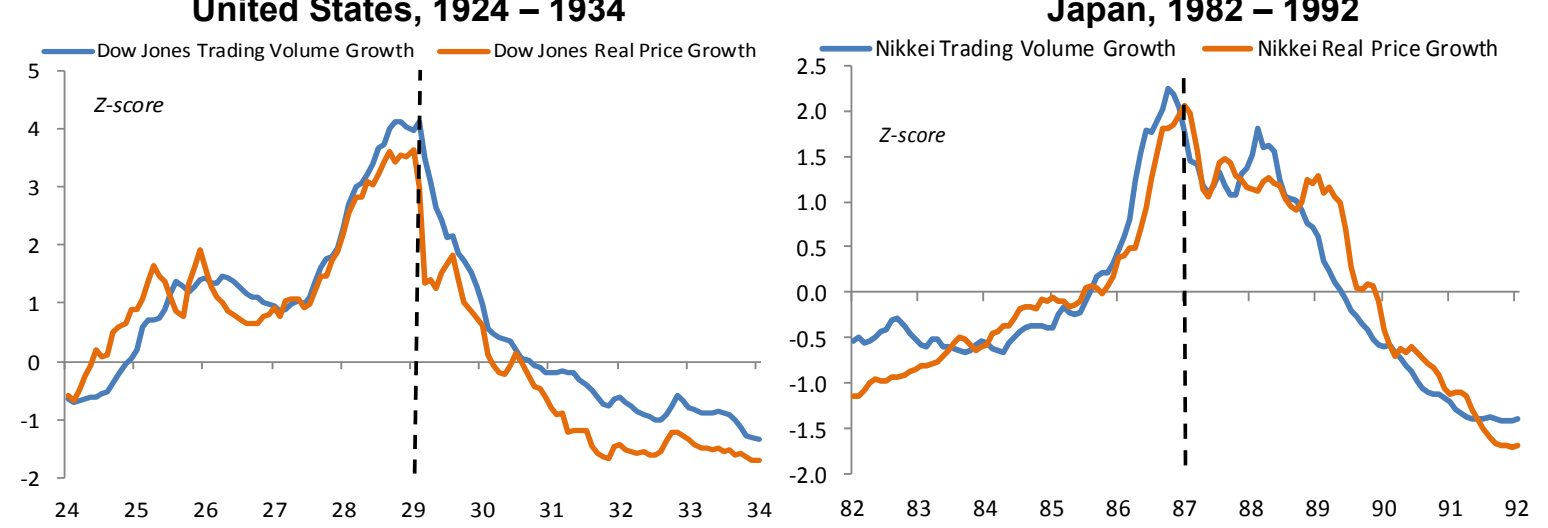

United States, 1995 - 2005

China, $2002-2012$

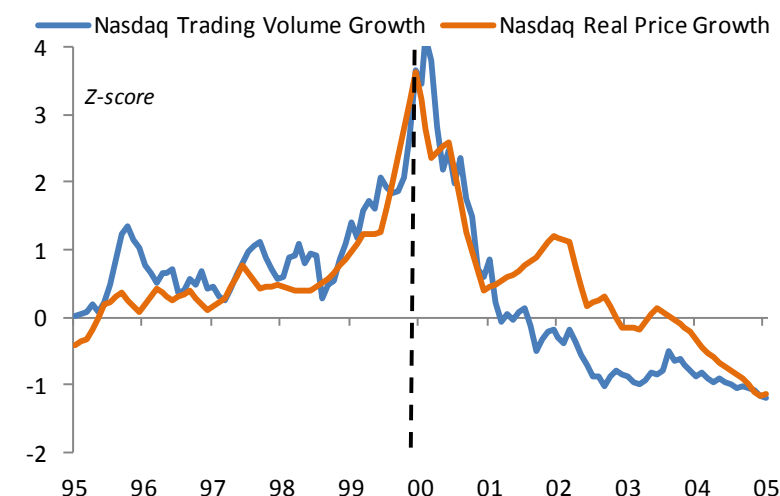

Source: Author's estimates, Bloomberg

Notes: The top panel depicts the simple average z-score for trading volume and real price growth (measured over five years) during the largest real price boom in the following 24 countries: Australia, Canada, Chile, China, France, Germany, Hong Kong, India, Indonesia, Italy, Japan, Korea, Mexico, Netherlands, Norway, Poland, Russia, Singapore, Spain, Sweden, Switzerland, Turkey, UK, and the U.S. 
At the present juncture, trading volumes appear to be most elevated by historical standards for low grade credit securities. Trading volumes in the cash high yield market have increased substantially in recent years, in absolute terms and relative to investment grade credit volumes (left hand panel, Figure 24). Trading volumes in the exchange traded fund (ETF) market for high yield and leverage loans securities have also picked up strongly (right hand panel, Figure 24). In contrast, growth in equity trading volumes has been subdued across world equity markets despite the rally in stock prices over recent years, a very different scenario to the euphoria of the late 1990s (Figure 25).

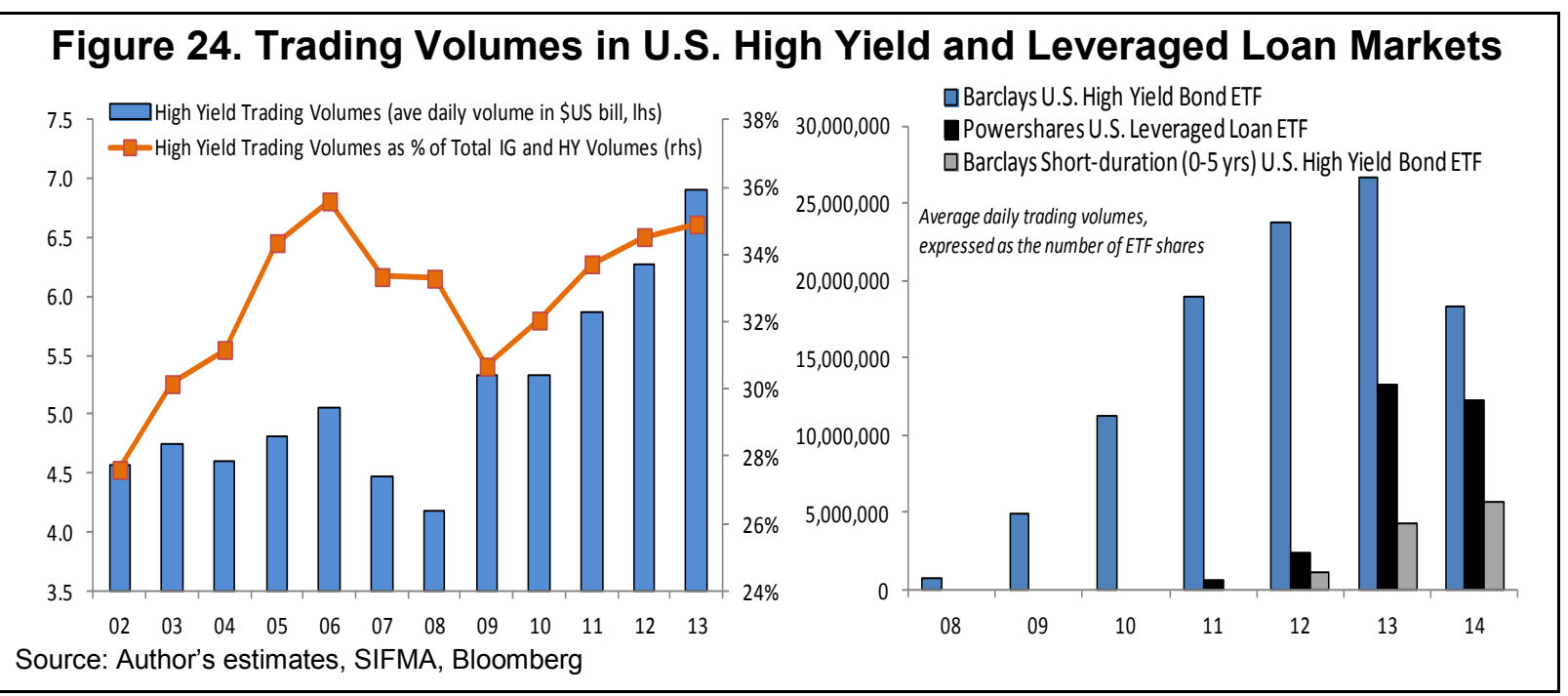

\section{Figure 25. Average Growth in Trading Volumes and Real Stock Prices across} 24 Countries (left), and Current Equity Trading Volumes (right)
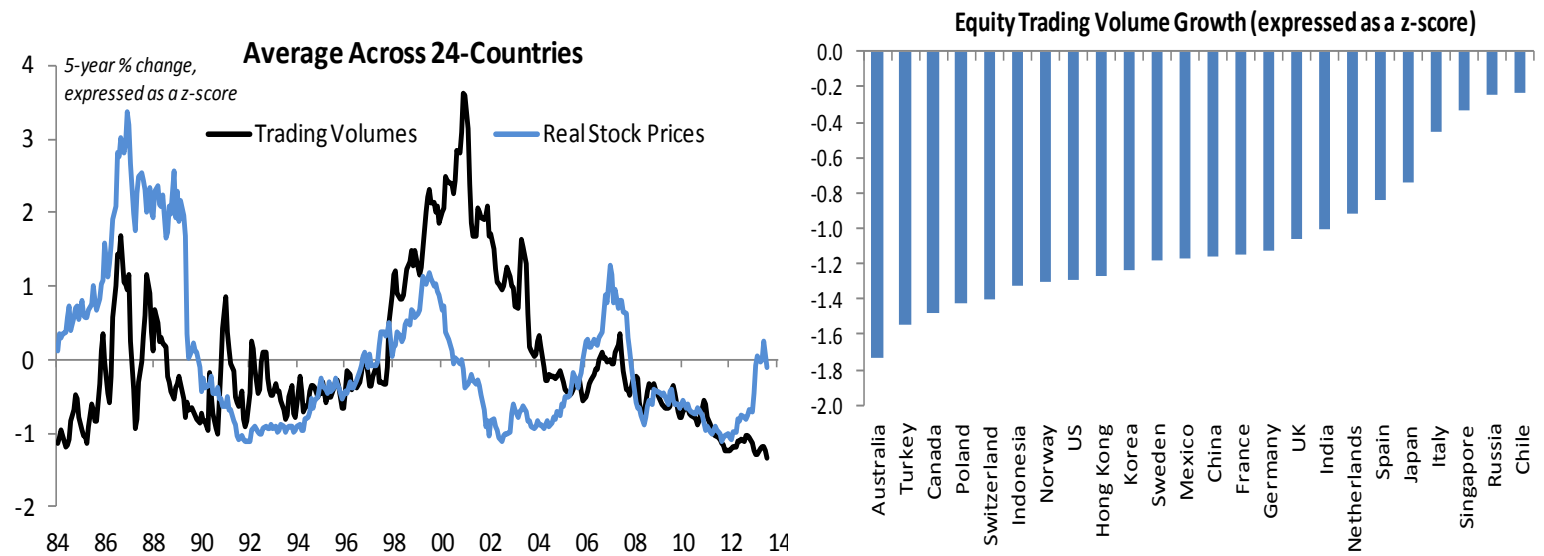

Source: Author's estimates, Bloomberg, Haver

Notes: Chart depicts the 5-year change in trading volumes and real stock prices, expressed as the number of standard deviations above or below the long-run country average. 


\section{(iii) Investor Fund Flows}

Though cross-border capital flows have long featured in the literature on balance of payments crises, only in recent times have researchers begun to examine the financial stability implications arising from herding and redemption patterns in institutional investment funds. Elevated fund flows can put upward pressure on prices (particularly in small or illiquid asset classes), which in turn attract more flows from underinvested and/or underperforming investors (Chevalier and Ellison, 1997, 1999; Vayanos and Woolley, 2013). There are few natural circuit breakers to this feedback loop. The fund flows of unlevered investment managers operating in the 'relative performance derby' vis-à-vis their peer group can be a locus of financial instability to the extent they are strongly motivated by herding considerations (Woolley, 2010; Cai and others, 2012; Feroli and others, 2014; Jones, 2014). ${ }^{36}$

The pattern of investor fund flows into and out of asset classes depicted in Figures 26 and 27 also suggest they should be monitored by authorities. Investor fund flows (based on EPFR data) appear to gradually rise over a period of years and peak at around one standard deviation above average just prior to a large decline in asset prices (Figure 26). In the subsequent bust, cumulative fund flows fall to more than one standard deviation below average before markets trough. There is a positive contemporaneous correlation between fund flows and risky asset class returns (left panel, Figure 27), Further, returns in emerging market debt and equity also tend to lead fund flows by one quarter. Interestingly, these correlation patterns are absent for relatively 'safe' Treasuries. Additionally, fund flows have been considerably stronger than usual for emerging markets and high yield credit immediately after these asset classes recorded their strongest ever returns (right panel, Figure 27), suggesting some degree of performance chasing in asset classes further out along the risk spectrum (this pattern is also absent in Treasuries). ${ }^{37}$

\footnotetext{
${ }^{36}$ Positive feedback trading can result from no manager wanting to be last in or last out, with the effect most pronounced in relatively risky and illiquid markets. Chen and others (2010) show that redemptions from mutual funds holding illiquid assets create incentives like those facing depositors in a bank run (see the classic model of Diamond and Dybvig, 1983). Money market funds can face a particularly acute form of vulnerability to runs.

${ }^{37}$ Using high frequency Lipper mutual fund data, Feroli and others (2014) also find fund flows and returns in the U.S. Treasury market to be relatively insensitive in both a contemporaneous and lead-lag sense. Safe liquid assets do not appear to be subject to the same speculative herding pressures as risky and/or illiquid assets.
} 


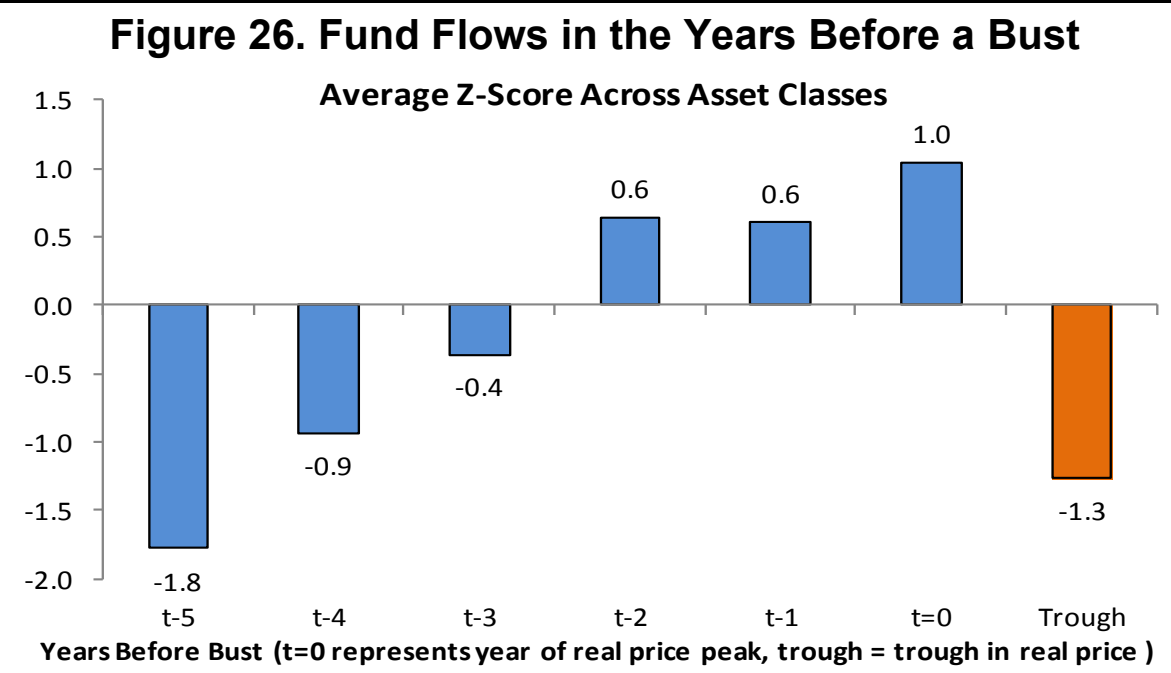

Source: Author's estimates, EPFR, Haver

Notes: Average z-score of cumulative three-year flows (normalized as a share of total fund assets) across developed market equity, emerging market equity, emerging market hard currency fixed income, emerging market local currency fixed income, global high yield credit, and U.S. Treasuries. A 'bust' is defined as the largest peak-to-trough decline in real returns for each asset class between 1996-2014 (or earliest available).

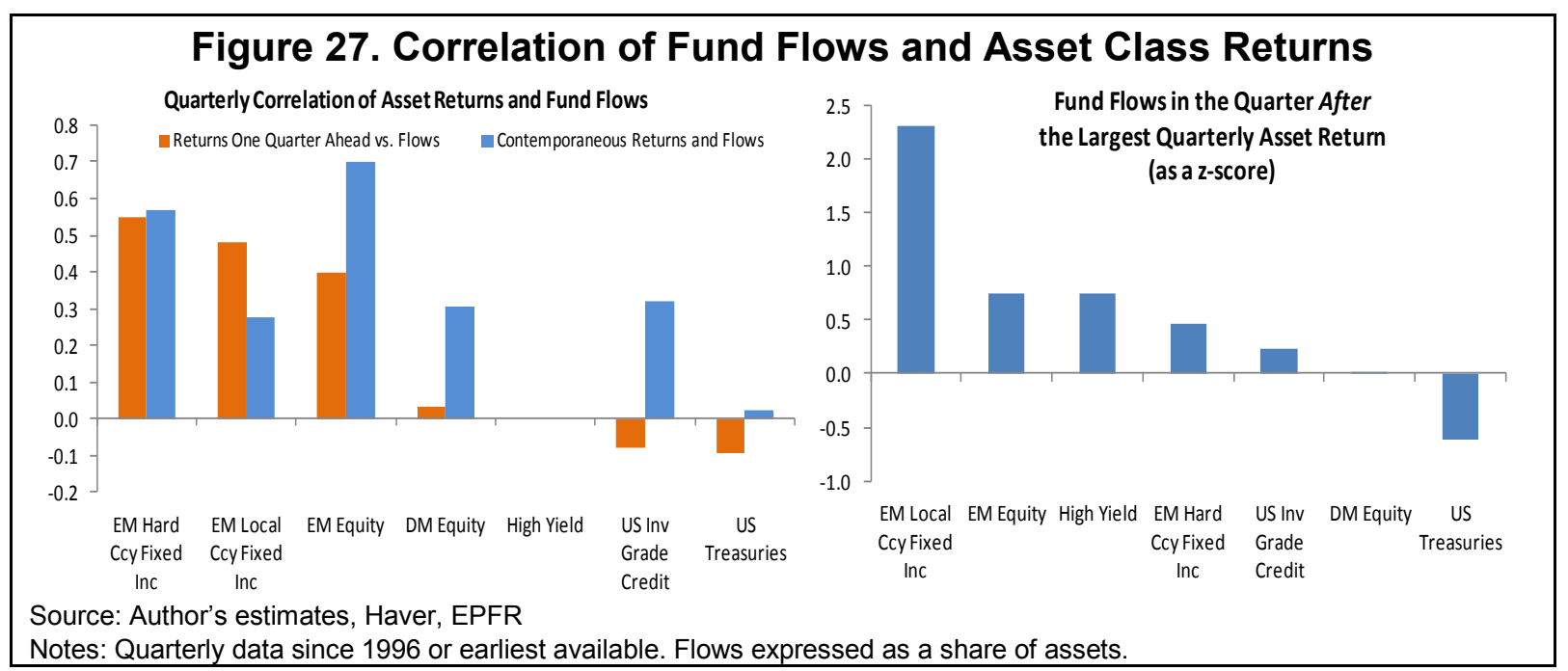

In the aftermath of the 2008 crisis, the most interesting fund flow activity has been concentrated in fixed income markets. The largest proportional increases in fund flows (i.e., relative to assets under management) have occurred in emerging market local currency bonds, and long- and short-term investment grade corporate bonds in developed markets (left panel, Figure 28). The particularly sharp increase in flows for emerging market local currency bonds likely exacerbated the effects of the 'taper tantrum' in the spring of 2013. Though emerging market bond inflows have tempered over the past year, in developed fixed income markets, flows into short-duration investment grade credit and high yield continue to be strong. In contrast to fixed income, the general fund flow picture for equity markets appears fairly benign. Though flows into emerging market equities surged 40 percent (relative to assets under management) in the first two years after the crisis, they have since 
tracked sideways (right panel, Figure 28). Only over the past 18 months have fund flows picked up to developed market equities, following six years of cumulative decline.

Though some of the robust post-crisis fund flows into fixed income markets could be attributable to slow-moving structural forces (including demographic and regulatory changes), events in the spring of 2013 suggest it is here where future interest rate shocks could be felt most acutely. Also relevant from a broader financial stability perspective is that the smallest (and by implication, least liquid) asset classes have received the proportionally largest fund flows over the past five years (Figure 29). ${ }^{38}$ This raises the risk of disorderly market movements in the event of future adverse liquidity shocks.

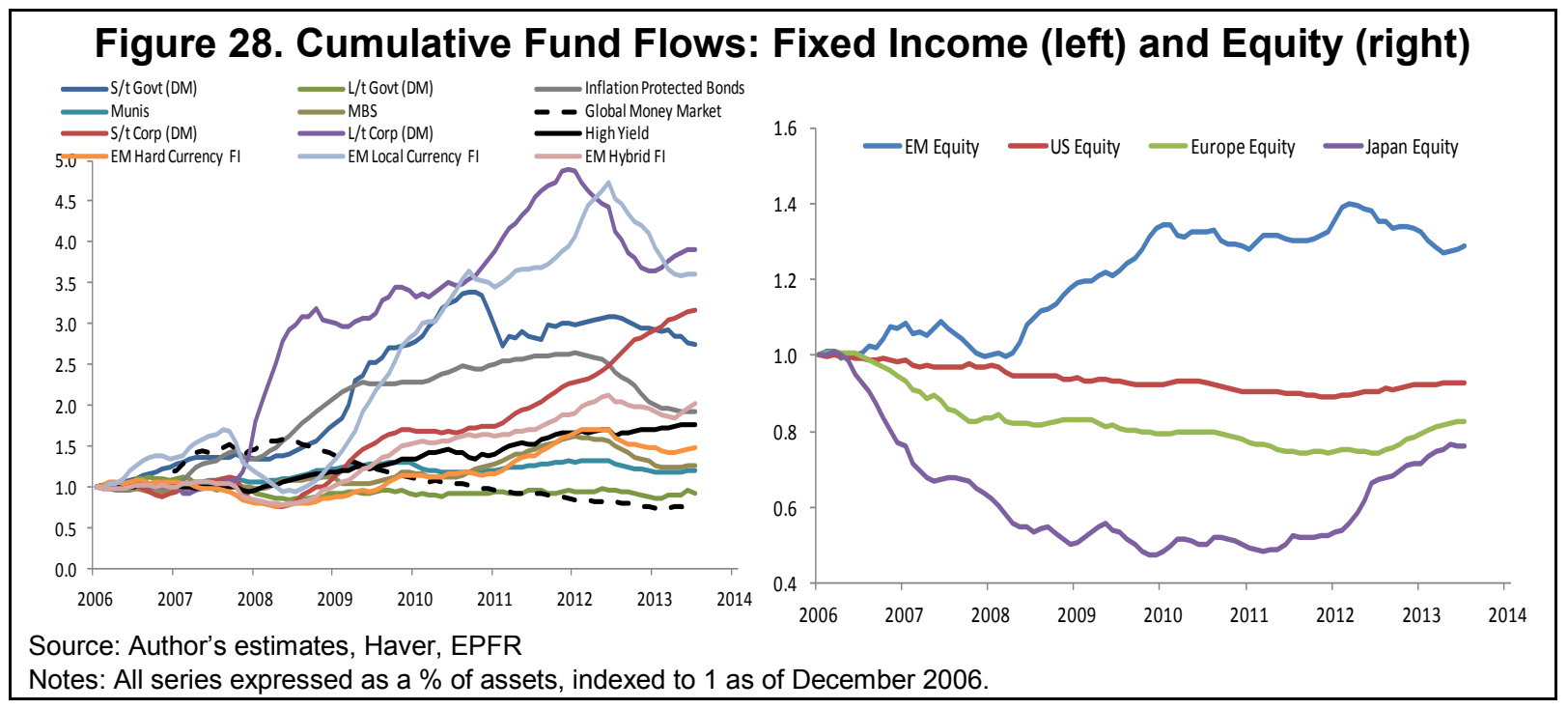

Figure 29. Size of Asset Class Funds vs. 5-Year Cumulative Fund Flows

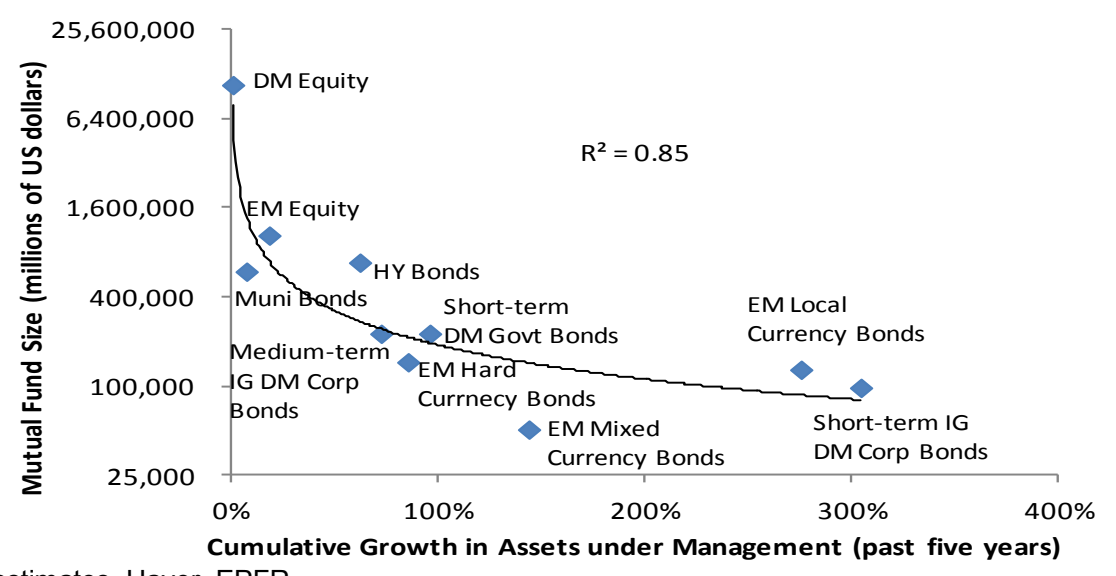

Source: Author's estimates, Haver, EPFR

Notes: Horizontal axis represents the growth in fund flows (as a \% of assets) from June 2009-June 2014.

\footnotetext{
${ }^{38}$ For a recent treatment of common global factors in cross-border portfolio flows, see IMF (2014).
} 


\section{(iv) Surveys of Return Expectations}

To the extent they highlight the irrational extrapolation of past returns into investor estimates of future returns, survey data may also serve as another tool in the asset bubble surveillance toolkit. Shiller (2000b) developed a survey-based indicator to assess whether stock market investors were buying stocks purely on the basis of expectations of a short term increase in the market. Muellbauer (2012) argues that central banks should regularly survey home buyers regarding their expectations for capital appreciation for this express purpose, especially where there might be a large degree of uncertainty over model-based estimates of 'fair value' (as is typically the case for housing). Survey data reveal that after a run up in asset prices, subjective expectations of returns tend to be high while objective expected returns tend to be low (Ilmanen, 2011; Greenwood and Shleifer, 2013; Williams, 2013).

Unlike past cyclical highs in the U.S. stock market, survey-based estimates of expected returns appear relatively benign at the present time (as a relatively new field of research, lengthy time series of investor expectations for risky asset returns have been compiled only for the U.S. stock market). At the peak of the 1990s equity bubble, investor return expectations (as measured by the Survey of Professional Forecasters, and the Duke University CFO Survey) were around three times higher than the (objective) cyclicallyadjusted earnings yield (Figure 30). Not only were return expectations high in the Duke CFO survey, they were also rising at the same time the earnings yield collapsed in response to booming stock prices. Just prior to the late-2007 market peak, survey-based return expectations were again rising and well above the earnings yield measure of future returns. In contrast, there are (as yet) few signs of wildly extrapolative return expectations this cycle survey-based return expectations are presently near historic lows.
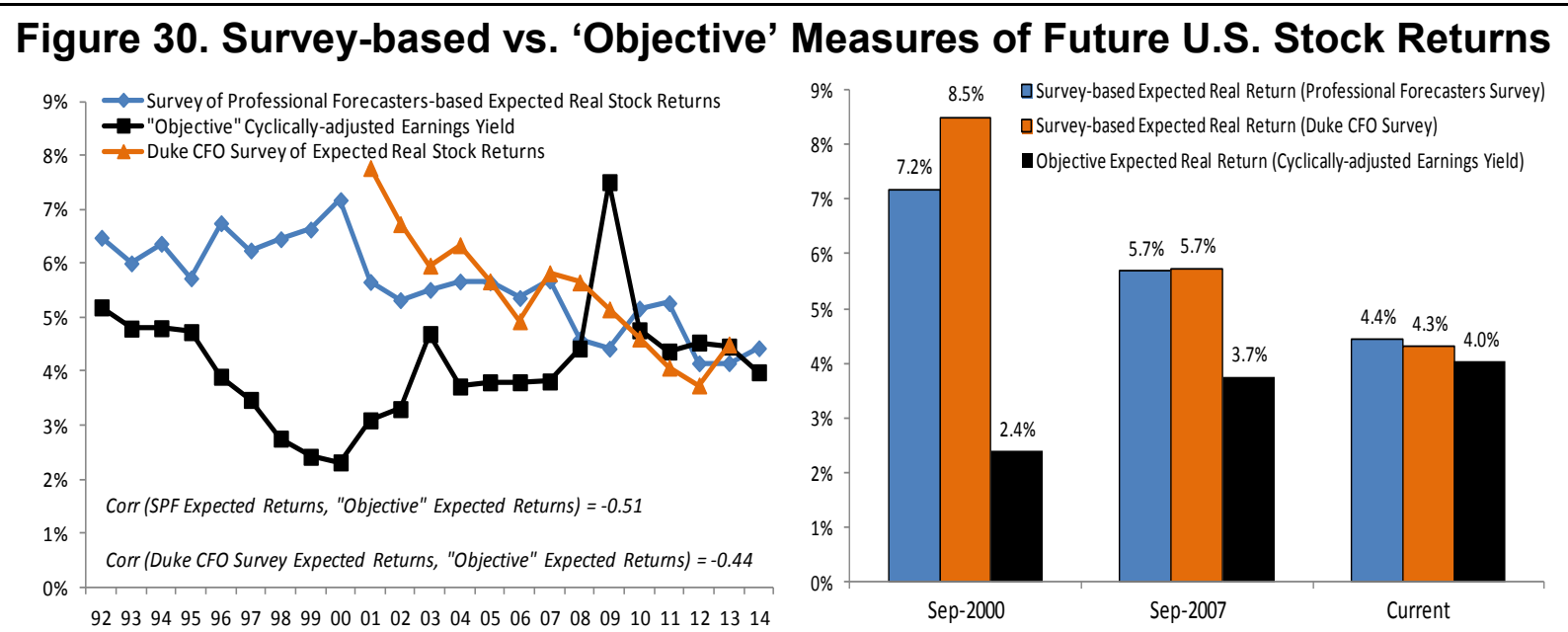

Source: Author's estimates, Duke Quarterly CFO Survey, Philadelphia Fed Survey of Professional Forecasters Notes: Latest survey estimates are as at Q1-2014. 'Objective' measure of future stock returns is the cyclically adjusted earnings yield calculated as the ratio of the ten-year moving average of earnings to stock prices. 


\section{Concluding Remarks and Future Research}

The cost of bursting bubbles, and the inability of authorities to identify the accumulation of excesses in asset markets prior to the global financial crisis, suggests the need for an augmented surveillance framework. While acknowledging that the identification of asset bubbles will always remain a difficult task-one that cannot be reduced to a single equation or model-the analysis presented in this paper suggests that a framework anchored in both price and non-price terms offers an encouraging starting point. Asset pricing models, no matter how elaborate, should be the place to begin, not finish, surveillance work. By measuring risk taking behavior, and financial vulnerabilities more generally, in ways that escape conventional asset valuation-based analysis, I argue quantity data offer a promising, complementary way to enrich our understanding of asset market dynamics.

At present, this two-pillar framework signals mounting fragilities in the market for lowlyrated U.S. corporates. Across global equity, sovereign debt, and corporate credit markets, it is only in the latter case where a consistent picture of aggressive risk-taking emerges in both price and non-price terms. Credit spreads for lowly-rated U.S. corporates are below levels required to compensate investors for an average default cycle, the quantity of issuance is unusually high, the composition of issuance is deteriorating in quality-adjusted terms, relative trading volumes for lowly rated securities are elevated, and fund flows for relatively illiquid credit securities have been particularly strong. In light of these risks, policy makers and regulators should be attune to any further deterioration in underwriting standards, and where possible, take steps to ensure the post-crisis financial infrastructure is braced to accommodate a material re-pricing in credit risk.

The broader issue of what policy makers should do about asset bubbles, while beyond the scope of the present analysis, constitutes a critical related objective of future research. In the aftermath of the global financial crisis, much emphasis has been placed on the role of monetary and macroprudential policy in circumventing conventional leverage-driven asset booms. However, the dimensions of the next crisis will not necessarily follow those of the most recent cycle. Characteristics of the rapidly growing asset management industryincluding incentives for asset managers to knowingly 'ride bubbles'-present policy makers with challenges that will likely require examination of a new suite of policy tools if authorities are to mitigate future threats to financial instability (Haldane, 2014; Stein, 2014; and Jones, 2014). In conjunction with ongoing analysis of early warning surveillance techniques, ${ }^{39}$ these areas should be fertile ground for future research.

\footnotetext{
${ }^{39}$ Although data limitations preclude the analysis of a formal weighting scheme between price and non-price data in this paper (non-price data are not available across countries and asset classes in the same manner of valuation data), this could be a fruitful line of inquiry in 'early warning' approaches.
} 


\section{Annex 1. Standard Testing Techniques for Speculative Bubbles}

The basic intuition underlying some of the empirical tests for speculative bubbles is outlined below:

- Variance-bounds tests: examine whether the ex-post rational price is at least as variable as observed prices, as the latter are based on expected cash flows and do not have the variation introduced by future forecast errors which the ex-post price includes (see Shiller, 1981; Grossman and Shiller, 1981; and Blanchard and Watson, 1982);

- Two-step tests: explicitly attempt to distinguish between model specification errors (with prices modeled as an autoregressive function of cash flows) and pricing behavior that would only be consistent with time-varying discount rates, and most likely bubbles (West, 1987);

- Integration/cointegration tests: tests for bubbles are based on whether an unobserved bubble process is stationary after differencing, and where the level of prices and cashflows are cointegrated (Diba and Grossman, 1988);

- Regime switches: the hurdle for identifying speculative bubbles is further raised by incorporating infinite holding periods and the low probability but high impact event of a policy change, such as to a tax law or currency regime (Flood and Hodrick, 1986; Flood and others, 1994). Expected regime switches, especially those that fail to materialize, pose a major problem for bubble detection because their observed impact on stock prices is similar to bubbles. Non-linear models that explicitly allow for regime-switching in observed fundamentals similarly raise the bar for establishing the presence of bubbles (Driffill and Sola, 1998).

- Time-varying discount rates and systemic or macroeconomic risk: examine the extent to which risk aversion covaries with aggregate consumption. Discount rates are mapped onto estimates of the business cycle and systemic risk. These models imply required returns are rationally lower when economic conditions are strong and vice versa (Fama and French, 1989; Campbell and Cochrane, 1999; Lettau and Ludvigson, 2001, Cochrane 2011). 


\section{Annex 2. Estimates of Required/Expected Returns}

Throughout the paper, the terminology 'expected' or 'required' returns is applied to the valuation of housing and stock markets (both of which are real assets with an undefined maturity that can be modeled as a perpetual running yield), while 'excess returns' refer to corporate bond spreads and risk premia in the government bond markets (i.e. nominal assets with a fixed maturity). Valuation estimates are derived as follows:

- Housing-constructed as a quarterly index of the ratio of rents to home prices. ${ }^{40}$ The rental series is the 'rent of primary residence' published by the Bureau of Labor Statistics. Nominal home price data are based on the series published in Shiller (2000a), with updates available in Haver.

- Stocks-expected real returns (into perpetuity) are defined as an equally weighted average of three models for the real discount rate backed out of current prices: ${ }^{41}$

(i) The cyclically-adjusted earnings yield, defined as the reciprocal of the ratio of prices to the seven year moving average of annual earnings per share for the MSCI country indices (aside from the longer U.S. series, which is based on S\&P500 data back to 1914 from the Robert Shiller website);

(ii) The forward-looking single stage Gordon growth dividend model, where: Price $=$ dividend per share / (long-term bond yield + equity risk premium long term GDP growth). Prices, (cyclically adjusted) dividends, and the longterm risk free rate can be directly observed. Long-term inflation and real GDP growth expectations are based on survey data reported by Consensus Economics beginning in 1989. Prior to this, expectations for nominal growth are proxied by the 10-year moving average of inflation and real GDP growth.

(iii) The forward-looking multi-stage 'H-model' of Fuller and Hsia (1984), where the growth rate of earnings per share in the first seven years is based on matching year GDP growth expectations, with an upward or downward adjustment based on the current level of profit margins so as to stabilize the profit to GDP ratio in the steady state. A constant (60 percent) payout ratio is

\footnotetext{
${ }^{40}$ Gallin (2008) finds the rent/price ratio to be useful for forecasting future U.S. home prices. While it is beyond the scope of the current paper, more elaborate 'user cost' models of home prices (incorporating other variables such as interest rates, running costs, and substitute rental costs) also offer promise in deriving long-run 'fair value' estimates for housing. The rent/price ratio should be a stationary series if it is to be meaningful.

${ }^{41}$ Welch and Goyal (2008) and Campbell and Thompson (2008) run a series of horse races for competing models of equity valuation. Although not the primary purposes of this paper, like these studies, it was difficult to find any specification which could rival the forecasting power of the simple cyclically-adjusted earnings yield, despite it containing no forward looking inputs.
} 
applied to (cyclically adjusted) earnings to ameliorate cross-country differences in dividend taxation policies. The yield curve out to seven years is used to discount the initial set of cash flows. Cash flows beyond seven years are modeled as a constant growth-rate perpetuity based on long-term growth and inflation expectations, and long term bond yields. Using observable spot prices, the pricing equation is solved iteratively such that observed market prices are consistent with future cash flows and discount rates. Long-term inflation and real GDP growth expectations are based on survey data reported by Consensus Economics from 1989. Prior to this, expectations for nominal growth are proxied by the 10-year average of inflation and real GDP growth.

- Credit-for U.S. investment grade bonds, duration matched spreads are based on the difference between Moody's seasoned Baa and Aaa bond yield series available via the St Louis Federal Reserve FRED service. For high yield bonds, duration-matched spreads are derived from the Bank of America Merrill Lynch BB+ corporate bond yield series available from Global Financial Data, and US Treasury bond yields.

- Government Bonds-motivated in part on Woodford (2003), the 'Wicksellian' bond risk premium is defined as the spread between the 5 year 5 year forward bond yield, and the equilibrium (or neutral) rate, which is proxied by long term consensus expectations of real growth and inflation over the same period (a negative Wicksellian risk premium suggests bond yields are too low relative to the neutral rate, as proxied by long-run estimates of growth and inflation). This is essentially a special case of the Taylor rule for the bond market, where the neutral rate is captured by long term consensus expectations of real growth and inflation, and the inflation and output gap are closed. ${ }^{42}$ Wherever possible, zero-coupon bond yields are used (in their absence, the yield to maturity).

Finally, real GDP growth and inflation expectations are measured on an annual basis out to ten years via a survey of professional forecasters compiled by Consensus Economics. These data, though not entirely free of limitations, are interesting from a number of perspectives: they are not subject to revisions or serious time lags as is the case for many macrofinancial time series routinely employed in studies of asset price predictability; they are available on a consistent cross-country basis; and they can capture market expectations of structural breaks or changes in macro variables (a particular issue for historical studies of emerging markets), upon which estimates of fundamentals are based. To the best of the author's knowledge, this is the first time such data have been used in a comparable study.

\footnotetext{
${ }^{42}$ While conventional bond risk premium models typically compare prevailing bond yields to model-derived estimates of future monetary policy expectations, these models have nothing to say directly about whether monetary policy settings are consistent with long-term growth and inflation.
} 


\section{References}

Abramovitz, Moses, 1956, "Resource and Output Trends in the U.S. since 1870." American Economic Review, 46(2) (Papers and Proceedings), pp. 5-23.

Alessi, Lucia and Carsten Detken, 2009, "Real Time Early Warning Indicators for Costly Asset Price Boom/Bust Cycles: A Role for Global Liquidity," ECB Working Paper Series, No. 1039.

Akerlof, George and Robert J. Shiller, 2009, Animal Spirits: How Human Psychology Drives the Economy, and Why It Matters for Global Capitalism (New Jersey: Princeton University Press).

Asness, Clifford S., 2014, “My Top 10 Peeves,” Financial Analysts Journal, Volume 70, Number 1.

Baker, Malcolm, and Jeffrey Wurgler, 2000, "The Equity Share in New Issues and Aggregate Stock Returns," Journal of Finance, Vol. 55, Issue 5, pp. 2219-57.

Baker, Malcolm, and Yuhai Xuan, 2009, "Under New Management: Equity Issuance and the Attribution of Past Returns,” Working Paper (Cambridge, MA: Harvard Business School).

Bank for International Settlements, 2012, "Operationalising the Selection and Application of Macroprudential Instruments," CFGS Papers, No. 48, December, 2012.

Bank for International Settlements, 2014, " $84^{\text {th }}$ Annual Report," Geneva, June 2014. Available via the Internet: http://www.bis.org/publ/arpdf/ar2014e.pdf.

Bernanke, Ben, 2008, "Fostering Sustainable Homeownership," National Community Reinvestment Coalition Annual Meetings, Washington D.C.

Bernstein, William J., and Robert D. Arnott, 2003, "Earnings Growth: The Two Percent Dilution," Financial Analysts Journal, Vol. 59 (September/October), No 5., pp. 47 - 55.

Black, Fisher, 1986, “Noise,” Journal of Finance, Volume 41 (December), Issue 3, pp. 529543.

Blanchard, Olivier J., and Mark W. Watson, 1982, "Bubbles, Rational Expectations and Financial Markets," NBER Working Paper 945, July. 
Bonner, William and Lila Rajiva, 2007, Mobs, Messiahs and Markets: Surviving the Public Spectacle in Finance and Politics (New Jersey: John Wiley \& Sons Inc.).

Cai, Fang, Song Han, and Dan Li, 2012, "Institutional Herding in the Corporate Bond Market," Board of Governors of the Federal Reserve System, International Finance Discussion Papers, Number 1071, December.

Campbell, John Y., and John H. Cochrane, 1999, "By Force of Habit: A Consumption-based Explanation of Aggregate Stock Market Behavior, ” Journal of Political Economy, Vol. 107, pp. 205-251.

Campbell, John Y., and Samuel B. Thompson, 2008, "Predicting Excess Stock Returns Out of Sample: Can Anything Beat the Historical Average?" Review of Financial Studies, Vol. 21, Issue 4, pp. 1509-1531.

Campbell, John Y., Andrew W. Lo and A. Craig MacKinlay, 1997, The Econometrics of Financial Markets (New Jersey: Princeton University Press).

Carlos, Ann, Larry Neal, and Kirsten Wandschneider, 2006, "Dissecting the Anatomy of Exchange Alley: The Dealings of Stockjobbers during and after the South Sea Bubble," Working Paper (Champaign, IL: University of Illinois).

Cassidy, John, 2010, “Interview with Eugene Fama," New Yorker Magazine, January 13, 2010. Available via the Internet:

http://www.newyorker.com/online/blogs/johncassidy/2010/01/interview-with-eugenefama.html.

Chancellor, Edward, 2000, Devil Take the Hindmost: A History of Financial Speculation, (New York: Farrar, Straus and Giroux).

Chen, Qi, Itay Goldstein and Wei Jiang, 2010, "Payoff Complementarities and Financial Fragility: Evidence from Mutual Fund Outflows," Journal of Financial Economics, Vol. 97, Issue 2, pp. 239-262.

Chevalier, Judith, and Glenn Ellison, 1997, "Risk Taking by Mutual Funds as a Response to Incentives," The Journal of Political Economy, Volume 105 (December), No.6, pp. 11671200 .

Chevalier, Judith, and Glenn Ellison, 1999, "Career Concerns of Mutual Fund Managers," Quarterly Journal of Economics, Vol. 114, No. 2, pp. 389-432.

Cochrane, John H., 2003, "Stock as Money: Convenience Yield and the Tech-Stock Bubble”, in Asset Price Bubbles: The Implications for Monetary, Regulatory and International 
Policies, edited by Hunter, William C., George G. Kaufman, and Michael Pomerleano (Cambridge, MA: MIT Press).

Cochrane, John H., 2011, "Presidential Address: Discount Rates," Journal of Finance, Vol. LXVI (August), No.4.

Covas, Francisco, and Wouter J. den Haan, 2006, “The Role of Debt and Equity Finance over the Business Cycle,” Bank of Canada Working Paper 2006-45, December.

Diamond, Douglas, and Philip Dybvig, 1983, "Bank Runs, Deposit Insurance, and Liquidity," Journal of Political Economy, Vol. 91, pp. 401-19.

Diba, Behzad, and Herschel Grossman, 1988, "Explosive Rational Bubbles in Stock Prices?" American Economic Review, Vol. 78 (June), pp. 520-30.

Driffill, John, and Martin Sola, 1998, "Intrinsic Bubbles and Regime Switching," Journal of Monetary Economics, Vol. 42, Issue 2 (July), pp. 357-373.

Fama, Eugene F., 1970, "Efficient capital markets: A review of theory and empirical work," Journal of Finance, Vol. 25, 383-417.

Fama, Eugene F., 1991, “Efficient Capital Markets: II,” Journal of Finance, Volume 46, Issue 5, pp. 1575-1617.

Fama, Eugene F., and Kenneth R. French, 1989, "Business Conditions and Expected returns on Stocks and Bonds," Journal of Financial Economics, Vol. 25, pp. 23-49.

Feroli, Michael, Anil K. Kashyap, Kermit Schoenholtz, and Hyun Song Shin, 2014, "Market Tantrums and Monetary Policy," Working Paper presented at the 2014 U.S. Monetary Policy Forum, New York, February 28. Available via the Internet:

http://research.chicagobooth.edu/igm/usmpf/2014.aspx?source=igm-em-usmpf14-20140221initial.

Flood, Robert P., and Peter M. Garber, 1994, Speculative Bubbles, Speculative Attacks, and Policy Switching, (Cambridge, MA: MIT Press).

Flood, Robert P., Robert Hodrick, and Paul Kaplan, 1994, “An Evaluation of Recent Evidence on Stock Price Bubbles," in Speculative Bubbles, Speculative Attacks, and Policy Switching, edited By Robert P. Flood and Peter M. Garber (Cambridge, MA: MIT Press).

Flood, Robert P., and Robert Hodrick, 1986, “Asset Price Volatility, Bubbles and Process Switching," Journal of Finance, Vol. 41 (September), pp. 831-42. 
Fuller, Russell J., and Chi-Cheng Hsia, 1984, “A Simplified Common Stock Valuation Model,” Financial Analysts Journal, Vol. 40 (September/October), pp. 49-56.

Gallin, Joshua, 2008, “The Long-Run Relationship between House Prices and Rents," Real Estate Economics, Vol. 36, Issue 4, pp. 635-658.

Garber, Peter M., 2001, "Famous First Bubbles: The Fundamentals of Early Manias," The Journal of Political Economy, Vol. 109 (October), No. 5, pp. 1150-1154.

Gerdesmeier, Dieter, Hans-Eggert Reimers and Barbara Roffia, 2009, “Asset Price Misalignments and the Role of Money and Credit," ECB Working Paper Series, No. 1068, July.

Gilchrist, Simon, Charles P. Himmelberg and Gur Huberman, 2004, "Do Stock Price Bubbles Influence Corporate Investment," Federal Reserve Bank of New York Staff Reports, No. 177, February.

Greenwood, Robin, and Samuel G. Hanson, 2013, "Issuer Quality and Corporate Bond Returns," Review of Financial Studies, Vol. 26 (June), No. 6, pp. 1483-1525.

Greenwood, Robin, and Andrei Shleifer, 2013, "Expectations of Returns and Expected Returns,” NBER Working Paper No. 18686, November, Cambridge, MA.

Grossman, Sanford J., and Robert J. Shiller, 1981, "The Determinants of the Variability of Stock Market Prices," American Economic Review, Vol. 71 (May), Issue 2, pp. 222-227.

Gurkaynak, Refet S., 2005, "Econometric Tests of Asset Price Bubbles: Taking Stock," Finance and Economics Discussion Series, The Federal Reserve Board Working Paper 200504, Washington D.C.

Guscina, Anastasia, Guilherme Pedras, and Gabriel Presciuttini, 2014, "First-Time International Bond Issuance-New Opportunities and Emerging Risks," IMF Working Paper No. 14/127 (Washington D.C.: International Monetary Fund).

Haldane, Andrew G., 2014, “The Age of Asset Management?” Speech at the London Business School, London, April.

Hamilton, James D., and Charles H. Whiteman, 1985, "The Observable Implications of SelfFulfilling Expectations,” Journal of Monetary Economics, Vol. 16, pp. 353-373.

Harrison, Michael J., and David Kreps, 1978, "Speculative Investor Behavior in a Stock Market with Heterogeneous Expectations," Quarterly Journal of Economics, Vol. 92, No. 2, May, pp. 323-336. 
Hicks, John R., 1946, Value and Capital, 2nd edition (London: Oxford University Press).

Hirshleifer, Jack, 1977, "The Theory of Speculation under Alternative Regimes of Markets," The Journal of Finance, Volume 32 (September), No. 4, pp. 975-999.

Hong, Harrison, Jose Scheinkman, and Wei Xiong, 2006, "Asset Float and Speculative Bubbles," Journal of Finance, Vol. 61, No.3 (June), pp. 1073-1117.

Hong, Harrison and Jeremy C. Stein, 2007, "Disagreement and the Stock Market," Journal of Economic Perspectives, Vol. 21, No. 2, Spring 2007, pp.109-128.

Hong, Harrison and David Sraer, 2013, "Quiet Bubbles," Journal of Financial Economics, Vol. 110, pp. 596-606.

Ilmanen, Antti, 2011, Expected Returns: An Investor's Guide to Harvesting Market Rewards, (United Kingdom: John Wiley \& Sons Ltd.).

International Monetary Fund, 2003, When Bubbles Burst, World Economic Outlook, Chapter 2, April (Washington D.C.: International Monetary Fund).

International Monetary Fund, 2014, “Global Liquidity—Issues for Surveillance," IMF Policy Paper, March 11 (Washington D.C.: International Monetary Fund).

Jones, Brad, 2014, "Speculative Asset Bubbles: A Review and Policy Roadmap," IMF Working Paper, Forthcoming.

Kaminsky, Graciela, Saul Lizondo and Carmen Reinhart, 1998, "Leading Indicators of Currency Crisis," Staff Papers, International Monetary Fund, vol. 45 (March), Number 1, pp. $1-48$.

Kaplan, Steven, and Jeremy C. Stein, 1993, "The Evolution of Buyout Pricing and Financial Structure in the 1980s," Quarterly Journal of Economics, Vol. 108 (May), pp.313-357.

Keynes, John M., 1930, A Treatise on Money (New York: Harcourt, Brace and Co.).

Keynes, John M, 1936, The General Theory of Employment, Interest, and Money (New York: Harcourt Brace).

Kindleberger, Charles P., 1978 (2011), Manias, Panics and Crashes (New York: Macmillan).

Kindleberger, Charles P., 1987, "Bubbles," in The New Palgrave. A Dictionary of Economics, edited by J. Eatwell, M. Milgate and P. Newman (London: MacMillan). 
Korajczyk, Robert A., and Amnon Levy, 2003, "Capital Structure Choice: Macroeconomic Conditions and Financial Constraints," Journal of Financial Economics, Vol. 68, pp. 75-109.

Korajczyk, Robert A., Deborah Lucas, and Robert L. McDonald, 1990, "Understanding Stock Price Behavior around the Time of Equity Issues" in Asymmetric information, Corporate Finance and Investment, edited by R. G. Hubbard (Chicago: NBER and University of Chicago Press).

Lettau, Martin, and Sydney Ludvigson, 2001, "Consumption, Aggregate Wealth and Expected Stock Returns,” Journal of Finance Vol. 56, pp. 815-849.

Loughran, Tim and Jay R. Ritter, 1995, “The New Issues Puzzle,” Journal of Finance, Vol. 50, Issue 1, pp. 23-51.

Loughran, Tim and Jay R. Ritter, 1997, “The Operating Performance of Firms Conducting Seasoned Equity Offerings,” Journal of Finance, Vol. 52, Issue 5, pp. 1823-1850.

Mackay, Charles, 1841 (1852), Memoirs of Extraordinary Popular Delusions, 3 Vols., R. Bentley, 1841, Revised version, under the title Memoirs of Extraordinary Popular Delusions and the Madness of Crowds (London: Office of the National Illustrated Library).

Minsky, Hyman, 1986, Stabilizing an Unstable Economy (New York: Columbia University Press).

Minsky, Hyman, 1992, “The Financial Instability Hypothesis.” Working Paper No. 74, The Jerome Levy Economics Institute of Bard College, New York.

Muellbauer, John, 2012, "When is a Housing Market Overheated Enough to Threaten Stability?" in Property Markets and Financial Stability, edited by Alexandra Heath, Frank Packer and Callan Windsor, Proceedings of a conference, Reserve Bank of Australia, Sydney, pp. 73-105.

Myers, Stewart C., and Nicholas S. Majluf, 1984, "Corporate Financing Decisions when Firms have Information Investors Do Not Have," Journal of Financial Economics, Vol. 13, pp. 187-221.

Nelson, William R., 1999, "The Aggregate Change in Shares and the Level of Stock Prices," Finance and Economics Working Paper Discussion Series 1999-08, Washington D.C.: Board of Governors of the Federal Reserve System.

Ofek, Eli, and Matthew Richardson, 2003, "Dotcom Mania: The Rise and Fall of Internet Stock Prices," Journal of Finance Vol. 58, pp. 1113-1137. 
Reinhart, Carmen M., and Kenneth S. Rogoff, 2009, This Time is Different: Eight Centuries of Financial Folly (New Jersey: Princeton University Press).

Ritter, Jay, 1991, “The Long-run Performance of Initial Public Offerings,” Journal of Finance, Vol XLVI, No. 1, pp. 3-27.

Rockwell, Charles S., 1967, "Normal Backwardation, Forecasting, and the Returns to Commodity Futures Traders," Food Research Institute Studies, Vol. 7, pp. 107-110.

Rosser, J. Barley, 2000, From Catastrophe to Chaos: A General Theory of Economic Discontinuities, Second Edition (Boston: Kluwer Academic Publishers).

Scheinkman, Jose and Wei Xiong, 2003, "Overconfidence and Speculative Bubbles," Journal of Political Economy, Vol. 111, No. 6, pp.1183-1219.

Schultz, Paul, 2003, "Pseudo Market Timing and the Long-Run Underperformance of IPOs," Journal of Finance, Vol. 68, No. 2, pp. 483-518.

Segoviano, Miguel, Bradley Jones, Peter Lindner, and Johannes Blankenheim, 2013, "Securitization: Lessons Learned and the Road Ahead," IMF Working Paper 13/255, (Washington D.C: International Monetary Fund).

Siegel, Jeremy J., 2003, "What is an Asset Price Bubble? An Operational Definition," European Financial Management, Vol. 9, No. 1, pp. 11-24.

Shiller, Robert J., 1981, "Do Stock Prices Move Too Much to be Justified by Subsequent Changes in Dividends," American Economic Review, June, Vol. 71, pp. 421-436.

Shiller, Robert J., 2000a, Irrational Exuberance (New Jersey: Princeton University Press).

Shiller, Robert J., 2000b, "Measuring Bubble Expectations and Investor Confidence," The Journal of Psychology and Financial Markets, Vol. 1, No. 1, pp. 49-60.

Shiller, Robert J., 2003, "Diverse Views on Asset Bubbles," in Asset Price Bubbles: The Implications for Monetary, Regulatory and International Policies, edited by Hunter, William, George Kaufman, and Michael Pomerlano (Cambridge, MA: MIT Press.)

Sobel, Robert, 1968, Panic on Wall Street (New York: Macmillan).

Stein, Jeremy C., 2013, "Overheating in Credit Markets: Origins, Measurement, and Policy Responses," At the "Restoring Household Financial Stability after the Great Recession: Why Household Balance Sheets Matter" Research Symposium, sponsored by the Federal Reserve Bank of St. Louis, St. Louis, Missouri, February 7. 
Stein, Jeremy C., 2014, "Incorporating Financial Stability Considerations into a Monetary Policy Framework," Remarks at the International Research Forum on Monetary Policy, Washington DC, March 21.

Stiglitz, Joseph E., 1990, "Symposium on Bubbles," Journal of Economic Perspectives, Vol. 4, No. 2, pp. 13-18.

Teoh, Siew Hong, Ivo Welch and T. J. Wong, 1998, "Earnings Management and the Underperformance of Seasoned Equity Offerings," Journal of Financial Economics, Volume 50, Issue 1, pp. 63-99.

Thomas, Gordon, and Max Morgan-Witts, 1979, The Day the Bubble Burst (New York: Doubleday \& Company).

Vayanos, Dimitri and Paul Woolley, 2013, “An Institutional Theory of Momentum and Reversal,” The Review of Financial Studies, Vol. 26, No. 5, pp.1087-1145.

Welch, Ivo, and Amit Goyal, 2008, "A Comprehensive Look at the Empirical Performance of Equity Premium Prediction," Review of Financial Studies, Vol. 21, Issue 4, pp. 1455 1508 .

West, Kenneth, 1987, “A Specification Test for Speculative Bubbles,” The Quarterly Journal of Economics 102 (August), pp. 553-80.

Williams, John, 2013, "Bubbles Tomorrow and Bubbles Yesterday, but Never Bubbles Today?," Speech to the National Association for Business Economics, San Francisco, CA, September 9. Available via the Internet: http://www.frbsf.org/ourdistrict/press/presidents-speeches/williams-speeches/2013/september/asset-price-bubblestomorrow-yesterday-never-today/.

Woodford, Michael, 2003, Interest and Prices (Princeton, NJ: Princeton University Press).

Working, Holbrook, 1953, "Futures Trading and Hedging," American Economic Review, Vol. 43 (June), pp. 314-343.

Working, Holbrook, 1962, "New Concepts Concerning Futures Markets and Prices," American Economic Review, Vol. 52 (June), pp. 431-459. 